\title{
Breaking Bankruptcy Priority: How Rent-Seeking Upends the Creditors' Bargain
}

\section{Citation}

Mark J. Roe \& Frederick Tung, Breaking Bankruptcy Priority: How Rent-Seeking Upends the Creditors' Bargain, 99 Va. L. Rev. 1235 (2013).

\section{Published Version}

http://www.virginialawreview.org/sites/virginialawreview.org/files/RoeTung_Proof.pdf

\section{Permanent link}

http://nrs.harvard.edu/urn-3:HUL.InstRepos:16251727

\section{Terms of Use}

This article was downloaded from Harvard University's DASH repository, and is made available under the terms and conditions applicable to Other Posted Material, as set forth at http:// nrs.harvard.edu/urn-3:HUL.InstRepos:dash.current.terms-of-use\#LAA

\section{Share Your Story}

The Harvard community has made this article openly available.

Please share how this access benefits you. Submit a story.

\section{Accessibility}




\title{
BREAKING BANKRUPTCY PRIORITY: HOW RENT-SEEKING
} UPENDS THE CREDITORS' BARGAIN

\author{
Mark J. Roe ${ }^{*}$ and Frederick Tung ${ }^{* *}$
}

INTRODUCTION 1236

I. BASIC PRIORITY 1243

A. The Bankruptcy Code's Basics ............................................... 1243

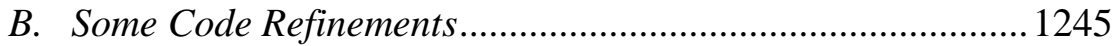

II. PRIORITY JumPInG AND ITS POLITICAL ECONOMY ..........................1246

A. An Integrated Process of Bankruptcy Rent-Seeking .............. 1246

B. Transactional Innovation and Litigation..............................1250

1. The DIP Lender's Priority Jump ...................................1250

2. The Critical Vendor's Priority Jump................................1254

3. The Section 363 Sale Priority Jump ............................... 1258

4. The SPV and Structured Finance Jump..........................1262

C. Lobbying for Priority: Rent-Seeking in Congress in the

Lead-Up to the Financial Crisis ...........................................1264

1. The Repo Recharacterization Jump.................................1265

2. The Derivatives Market's Priority Jump ......................... 1267

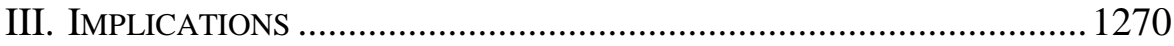

A. Dynamic Creditor Bargains ................................................ 1271

B. Is Priority Jumping Efficient? .............................................. 1272

1. Ex Post Costs: Adjusting to Priority Jumps .....................1273

2. Ex Ante Influence Costs and the Costs of Uncertainty....1275

CONCLUSION 1279

APPENDIX. ADDITIONAL CONTEMPORARY AND HISTORICAL PRIORITY

JUMPS

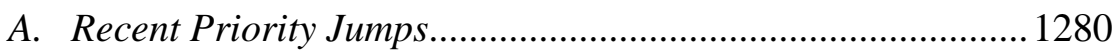

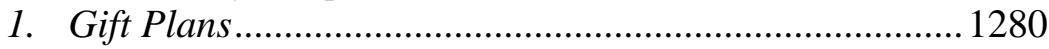

2. LBO Fraudulent Transfer Risk and the Section 546(e) Liability Insulator.

3. Section 510(b) and Fair Funds Securities Fraud

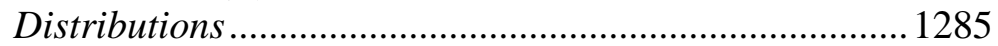

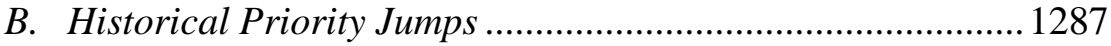

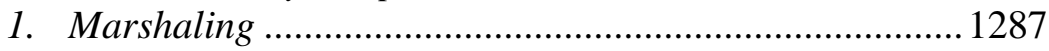

\footnotetext{
* David Berg Professor of Corporate Law, Harvard Law School.

** Howard Zhang Faculty Research Scholar and Professor of Law, Boston University School of Law.
} 


\section{INTRODUCTION}

$\mathrm{B}_{\mathrm{pring}}^{\mathrm{A}}$ ANKRUPTCY priority rules are fixed-or so it seems. Absolute priority is central to the structure of business reorganization and is, quite appropriately, bankruptcy's most important and famous rule. ${ }^{1} \mathrm{Be}-$ cause a firm in bankruptcy lacks sufficient value to repay all its creditors, priority rules determine the order of payment. The absolute priority rule commands that when distributing value in bankruptcy, claimants' priorities outside of bankruptcy are honored inside bankruptcy. ${ }^{2}$ The rule is sufficiently ingrained in bankruptcy thinking that, as its name suggests, priority must be immutable. It is absolute. On this view, the normal science of Chapter 11 corporate reorganization involves primarily the resolution and compromise of legal and factual ambiguities relating to creditors' competing priorities. The absolute priority rule provides the fixed framework within which the players negotiate the plan of reorganization and within which the judge evaluates it. ${ }^{3}$

The immutability of priorities is so central to our understanding of corporate reorganization that violations of absolute priority are troubling, ${ }^{4}$ deserving careful study and detailed explication. "Explaining ... deviations [from absolute priority] has been a central preoccupa-

\footnotetext{
${ }^{1}$ See Case v. L.A. Lumber Prods. Co., 308 U.S. 106, 116 (1939) (stating that the absolute priority rule is the fixed principle for evaluating reorganization plans); N. Pac. Ry. Co. v. Boyd, 228 U.S. 482, 502 (1913) ("[A] transfer by stockholders from themselves to themselves cannot defeat the claim of a non-assenting creditor.”); David Gray Carlson, Bankruptcy’s Organizing Principle, 26 Fla. St. U. L. Rev. 549, 606 (1999); G. Marcus Cole \& Todd J. Zywicki, Anna Nicole Smith Goes Shopping: The New Forum-Shopping Problem in Bankruptcy, 2010 Utah L. Rev. 511, 512 (stating that absolute priority has been a foundational element of corporate reorganization since bankruptcy laws have existed in the United States); Bruce A. Markell, Owners, Auctions, and Absolute Priority in Bankruptcy Reorganizations, 44 Stan. L. Rev. 69, 74-84 (1991) (describing the absolute priority rule as foundational).

${ }^{2}$ The absolute priority rule mandates that absent the consent of senior creditors, junior creditors are entitled to no bankruptcy distribution unless and until senior creditors are paid in full. See 11 U.S.C. $\S 1129$ (b) (2006).

${ }^{3}$ David L. Buchbinder, A Practical Guide to Bankruptcy 311-14 (1990); David G. Epstein et al., Bankruptcy $\S 11-25$, at 839 (1993).

${ }^{4}$ See, e.g., Allan C. Eberhart et al., Security Pricing and Deviations from the Absolute Priority Rule in Bankruptcy Proceedings, 45 J. Fin. 1457, 1468 (1990); Lawrence A. Weiss, Bankruptcy Resolution, 27 J. Fin. Econ. 285, 299 (1990).
} 
tion of reorganization scholars for decades." ${ }^{5}$ The incidence and magnitude of bankruptcy distributions not conforming to absolute priority are repeatedly analyzed in both the legal and finance literature. ${ }^{6}$ Oftentimes investigators explain why their results, when properly analyzed, did not violate priority after all. ${ }^{7}$ Deviations beg for correction.

Despite this perception that bankruptcy's priority rules are fixed, they are in fact regularly contested. Important ones regularly change. Of course, local priority disputes occur unremarkably: Courts routinely apply settled priority law to contested facts to resolve claims in particular cases. But this commonplace phenomenon is not the process that we have in mind. Beyond the normal science of litigation and negotiation over the application of settled rules to particular facts, the process we suggest involves changes in priority rules that affect distributional rights globally. The bankruptcy process is in fact rife with rent-seeking, as creditors and their professionals contest existing distribution rules and seek categorical changes to improve their private bankruptcy returns. Priority is not in fact absolute. It is often up for grabs.

This pursuit of priority change is continual and multi-dimensional, fought in multiple legal forums - from the transactional lawyers' offices to the bankruptcy courts to Congress. Investors, creditors, and managers invent innovative transactions that enhance their priority. They persuade judges that old priorities are wrong and new priorities are justified. And they turn to Congress to legislate new priority rules. This rent-seeking process is understood to be central to corporate law, securities law, and financial regulation ${ }^{8}$ - particularly when legislatures and administrative

\footnotetext{
${ }^{5}$ Douglas G. Baird \& Donald S. Bernstein, Absolute Priority, Valuation Uncertainty, and the Reorganization Bargain, 115 Yale L.J. 1930, 1930 (2006).

${ }^{6}$ See, e.g., Brian L. Betker, Management's Incentives, Equity’s Bargaining Power, and Deviations from Absolute Priority in Chapter 11 Bankruptcies, 68 J. Bus. 161, 161 (1995) (examining the cross-sectional determinants of absolute priority deviations in Chapter 11 bankruptcies); Julian R. Franks \& Walter N. Torous, An Empirical Investigation of U.S. Firms in Reorganization, 44 J. Fin. 747, 768 (1989) (finding deviations from absolute priority); Lynn M. LoPucki \& William C. Whitford, Bargaining over Equity's Share in the Bankruptcy Reorganization of Large, Publicly Held Companies, 139 U. Pa. L. Rev. 125, 126 (1990) (analyzing deviations from absolute priority empirically).

${ }^{7}$ See, e.g., Betker, supra note 6, at 162-63, 181-82 (arguing that shareholders' priority jumps in Chapter 11 result from creditors' voluntary acquiescence to shareholders' demands in order to speed up bankruptcy proceedings); LoPucki \& Whitford, supra note 6, at 143-58 (proposing several strategic explanations for priority jumps).

${ }^{8}$ Richard L. Hasen, Lobbying, Rent-Seeking, and the Constitution, 64 Stan. L. Rev. 191, 197, 232-34 (2012); Robert H. Sitkoff, Corporate Political Speech, Political Extortion, and the Competition for Corporate Charters, 69 U. Chi. L. Rev. 1103, 1112-13 (2002).
} 
agencies are lobbied-but to date has not been central to our conceptualizations of bankruptcy. With this Article, we aim to remedy that deficiency.

Recent years have witnessed important, successful priority jumps through doctrinal innovations in the courts. Trade creditors now regularly jump priority by persuading bankruptcy courts to designate them as critical vendors to the debtor firm. This entitles them to early and full payment of their pre-bankruptcy claims, instead of the pro rata "ten cents on the dollar" that unsecured creditors conventionally receive in the absence of any priority jump. At the same time, bank lenders have convinced judges to "roll up" their possibly unsecured pre-bankruptcy debts-debts that were quite likely not entitled to priority payment-into new, secured, and highly-prioritized loans to the debtor in bankruptcy. ${ }^{9}$

Other interested parties have pursued priority jumping through private ordering-sometimes within the formal bankruptcy process and sometimes outside it. For example, when debtors have sold business units during the bankruptcy proceeding via Section 363 sales, favored creditors have sometimes had their claims assumed by the acquirer as part of the sale, effectively jumping ahead of the disfavored creditors left behind. ${ }^{10}$ Structured finance deals, crafted well before bankruptcy, enable investor-creditors of debtor-sponsored special purpose vehicles to enjoy priority over the debtor's other creditors should the firm find itself in bankruptcy. ${ }^{11}$

Creditors also go to Congress for favored treatment. The range and impact of these congressional efforts have not been small nor have they been economically unimportant: Legislative priority-jumping facilitated the explosive growth of unstable financial techniques that preceded the 2007-2009 financial crisis. The massive derivatives market, for example, owes its existence in part to Congress according super-priority to critical parts of the derivative debt contract. ${ }^{12}$ Similarly, the gargantuan

\footnotetext{
${ }^{9}$ See infra Subsection II.B.1.

${ }^{10}$ Most $\S 363$ sales do not proceed that way, but some do. See infra Subsection II.B.3.

${ }^{11}$ See infra Subsection II.B.4.

${ }^{12}$ See Franklin R. Edwards \& Edward R. Morrison, Derivatives and the Bankruptcy Code: Why the Special Treatment?, 22 Yale J. on Reg. 91, 95-99 (2005); Mark J. Roe, The Derivatives Market's Payment Priorities as Financial Crisis Accelerator, 63 Stan. L. Rev. 539, 541, 546-54 (2011); Timothy P.W. Sullivan, Comment, Swapped Disincentives: Will Clearinghouses Mitigate the Unintended Effects of the Bankruptcy Code's Swap Exemptions?, 80 Fordham L. Rev. 1491, 1510-12 (2011); Bryan G. Faubus, Note, Narrowing the Bankruptcy Safe Harbor for Derivatives to Combat Systemic Risk, 59 Duke L.J. 801, 820-23 (2010).
} 
repo market would not have been viable without the extra priorities Congress accorded to repo debt, ${ }^{13}$ which figured prominently in major financial firm failures during the financial crisis. Early in the crisis, for example, Bear Stearns collapsed with an over-extended repo financing structure, triggering a "run on repo," which imperiled a number of other financial firms. ${ }^{14}$ With a bankruptcy commission organized by the American Bankruptcy Institute planning to submit a plan to Congress for a new Bankruptcy Code within the next two years, ${ }^{15}$ one can expect more such rent-seeking to reveal itself.

Though the pursuit of priority jumps has become a regular activity for bankruptcy lawyers, lobbyists, and interested creditor groups, scholars and policy makers have not yet analyzed the generality of this rentseeking activity or incorporated it into our conceptualization of bankruptcy. Instead, bankruptcy's standard positive and normative conceptualization is contractarian, ${ }^{16}$ viewing bankruptcy as in fact, or aspirationally, a hypothetical creditors' bargain: "a system designed to mirror the agreement one would expect the creditors to form among themselves were they able to negotiate such an agreement from an ex ante position."17 Under this framework, inter-creditor priorities in bankruptcy

\footnotetext{
${ }^{13}$ See Gary Gorton \& Andrew Metrick, Regulating the Shadow Banking System, Brookings Papers on Econ. Activity, Fall 2010, at 261, 276-77, available at http://www.brookings. edu/ /media/Projects/BPEA/Fall\%202010/2010b_bpea_gorton.pdf; see also infra Subsection II.C.1. Agreements to repurchase securities, known in the trade as "repos," are common financing mechanisms. A firm finances a security that it owns by simultaneously selling it and agreeing to repurchase it later.

${ }^{14}$ Gorton \& Metrick, supra note 13, at 276-77; see also Gary Gorton \& Andrew Metrick, Securitized Banking and the Run on Repo, 104 J. Fin. Econ. 425, 447-48 (2012). The repos get super-priority in bankruptcy, facilitating their widespread use. Overnight repo financing of heavily-leveraged firms, such as Bear Stearns, Lehman Brothers, and MF Global, makes them more fragile, and subject to rapid failure.

${ }^{15}$ Robert J. Keach \& Albert Togut, Commission to Explore Overhauling Chapter 11, 30 Am. Bankr. Inst. J. 36, 36, 38 (2011).

${ }^{16}$ Thomas H. Jackson, The Logic and Limits of Bankruptcy Law 17 (1986) [hereinafter Jackson, Logic and Limits]; Douglas G. Baird, The Uneasy Case for Corporate Reorganizations, 15 J. Legal Stud. 127, 127-28 (1986); Thomas H. Jackson, Bankruptcy, NonBankruptcy Entitlements, and the Creditors’ Bargain, 91 Yale L.J. 857, 860, 866-67 (1982) [hereinafter Jackson, Creditors' Bargain]; Thomas H. Jackson \& Robert E. Scott, On the Nature of Bankruptcy: An Essay on Bankruptcy Sharing and the Creditors' Bargain, 75 Va. L. Rev. 155, 155-56, 160 (1989); Donald R. Korobkin, Contractarianism and the Normative Foundations of Bankruptcy Law, 71 Tex. L. Rev. 541, 542-45 (1993); Lynn M. LoPucki, A Team Production Theory of Bankruptcy Reorganization, 57 Vand. L. Rev. 741, 742-44 (2004); Alan Schwartz, A Contract Theory Approach to Business Bankruptcy, 107 Yale L.J. 1807, 1819-20 (1998).

${ }^{17}$ Jackson, Creditors' Bargain, supra note 16, at 860.
} 
generally mirror their priorities as state law creates them outside of bankruptcy. ${ }^{18}$ Bankruptcy creates further priorities only to the extent necessary for the collective proceeding that implements the creditors' bargain to succeed. ${ }^{19}$

That the reality of rent-seeking remains unexamined is unsurprising. The notion that priority could be regularly up for grabs across multiple forums clashes with the more congenial conventional view of bankruptcy as a court-centered contract enforcement mechanism, honoring the debtor's obligations according to established non-bankruptcy priorities to the extent the debtor's limited pool of value allows. We contend, however, that priority jumping is core to the normal science of corporate reorganization.

Rather than viewing Chapter 11 as a set-piece application of fixed priority rules within bankruptcy courts, the bankruptcy process should be seen as a continuing struggle among creditor groups to break priority, both within and outside the courts. Priority jumps are not isolated or idiosyncratic. We document their regularity in recent years, and we revisit several historically important priority jumps. Pursuing or maintaining priority jumps is a staple activity among organized creditor groups and their professionals. These regular changes to bankruptcy priority not only alter bankruptcy distributions but also attract resources in the competitive pursuit of further favor from Congress and the courts. Priority jumps beget more priority-jumping activity, ${ }^{20}$ either by successful creditors seeking more or by recently jumped creditors seeking to reverse or minimize their loss from the latest priority jump. ${ }^{21}$

It may seem counterintuitive to conceptualize priority-jumping activity as part of the normal science of corporate restructuring. After all, politics occurs in Congress, while bankruptcy practice occurs in the courts, or in the conference rooms where deals are made and companies are fi-

\footnotetext{
${ }^{18}$ See Jackson, Logic and Limits, supra note 16, at 22 ("[I]n its role as a collective debtcollection device, bankruptcy law should not create rights. Instead, it should act to ensure that the rights that exist are vindicated to the extent possible.").

${ }^{19}$ Id. at 153 (explaining why the administrative expense priority is justified in creditors' bargain terms).

${ }^{20}$ See Gordon Tullock, Rent Seeking 70-74 (Charles K. Rowley ed., 1993).

${ }^{21}$ See, e.g., In re Lehman Bros. Holdings, 452 B.R. 31, 35-37, 43 (Bankr. S.D.N.Y. 2011) (denying parties' efforts to alter derivatives priority); In re Lehman Bros. Holdings, 439 B.R. 811, 834-37 (Bankr. S.D.N.Y. 2010) (rejecting creditor's effort to validate triangular derivatives setoff as permissible under § 560); In re Kmart Corp., 359 F.3d 866, 868, 874 (7th Cir. 2004).
} 
nanced. This court-centered, deal-oriented perspective is an artifact of bankruptcy's institutional setting. Other business-based administrative processes are run not by courts but by government agencies that regularly interact with affected constituencies and Congress, and typically act through public rulemaking processes. Rent-seeking in this setting is common and often transparent. ${ }^{22}$ In securities regulation and financial regulation - kindred fields to corporate reorganization - the affected private parties and their lawyers regularly lobby public officials to shape broad-based rules. Administrative agencies like the Securities and Exchange Commission and the banking regulators are headed by political appointees. The regulators effectively report to Congress, on which they depend for their budgets. In contrast, courts run the bankruptcy process. No one doubts that the financial industry is deeply involved in constructing financial law and regulation. But the courts are removed from the political process; they make rules primarily as a byproduct of litigation. So it seems natural to view bankruptcy as a court-centered, largely apolitical process - one susceptible to a largely contractarian understanding based on fixed rules.

But both courts and Congress have entertained all manner of priorityjumping proposals in recent decades and have acted on many. Rentseeking efforts play no solid institutional favorites, occurring in every setting from which bankruptcy priority rules issue-contracting, litigating, and legislating. ${ }^{23}$

We briefly consider the consequences of jumping priority, from both efficiency and political economy perspectives. A priority jump can lead to more efficient risk allocation. Creditors disadvantaged by a priority jump adjust, ${ }^{24}$ realizing that they face greater credit risk than before the jump because a newly favored creditor has moved ahead in the line for repayment. The jumped creditors adjust over time, in a manner understood formally in the famous-in-finance, Nobel Prize-winning Modigliani-Miller irrelevance propositions. But if the jumped creditors adjust more slowly than the nimble jumping creditors, value transfers

\footnotetext{
${ }^{22}$ Frank R. Baumgartner et al., Lobbying and Policy Change: Who Wins, Who Loses, and Why 166-89 (2009).

${ }^{23}$ On rent-seeking efforts generally, see Anne O. Krueger, The Political Economy of the Rent-Seeking Society, 64 Am. Econ. Rev. 291 (1974) (modeling the costs of competitive rent-seeking).

${ }^{24}$ Stockholders are typically out of the picture in a major modern bankruptcy, regardless of creditor priorities.
} 
occur and such jumps make for winners and losers. Often creditors adjust by rushing to join the favored creditor classes. The resulting financing patterns can change firms' financial structures, sometimes for the worse. ${ }^{25}$ If priority jumps favor short-term creditors, for example, then firms will end up with more short-term, often unstable, credit.

This process can, however, be efficient if the cheaper credit from jumping priority derives from lenders' lowered costs of evaluating, monitoring, and managing credit portfolios, and if those benefits outweigh the costs that the disfavored creditors incur plus the social losses from creditors pursuing priority jumps in the first place. ${ }^{26}$ Hence, some priority jumps will be efficient, some inefficient. On the inefficiency side of the ledger, creditors may seek a priority jump, not because of its ultimate transactional efficiency, but because they can react quickly and shift losses to less nimble creditors or because they enjoy a comparative advantage in obtaining priority in one decisional forum or another. The less nimble may suffer from institutional or cognitive scleroses that impede them from reacting rapidly and effectively. The overall costs of priority-seeking may therefore not be trivial. Especially when the process becomes competitive, the total cost spent pursuing and contesting priority jumps may swamp any efficiency gains from streamlined credit provisions. $^{27}$

Many, perhaps most, priority jumps in recent years show strong indicia of having been inefficient overall, even if some were locally efficient in one deal or another. Too many resemble the classic rent-seeking story applied to the costs of monopolization: If monopoly profits are high enough, social resources will be over-spent as parties pay for a chance of obtaining those monopoly profits. ${ }^{28}$ We offer examples of priority jumping in which rent-seeking costs are likely to have dominated any transactional efficiencies. While we do not seek to evaluate fully the efficiency implications of priority jumping, there is good reason to surmise that it generates many inefficiencies and that priority jumping contributed to

\footnotetext{
${ }^{25}$ Cf. Roe, supra note 12, at 542 (analyzing how the Bankruptcy Code’s superpriority provisions incentivize risky pre-bankruptcy strategies).

${ }^{26}$ On the costs of rent-seeking, see generally Toward a Theory of the Rent-Seeking Society (James M. Buchanan et al. eds., 1980) and The Political Economy of Rent-Seeking (Charles K. Rowley et al. eds., 1988).

${ }^{27}$ See Krueger, supra note 23, at 295, 302.

${ }^{28}$ Richard A. Posner, The Social Costs of Monopoly and Regulation, 83 J. Pol. Econ. 807, 807 (1975); Gordon Tullock, The Welfare Costs of Tariffs, Monopolies, and Theft, 5 W. Econ. J. 224, 228-32 (1967).
} 
the emergence and explosive growth of unstable financial techniques that contributed to the severity of the 2007-2009 economic crisis.

A roadmap for this Article: In Part I, we will outline baseline absolute priority. We will show how fixed priority is central to the conventional static conceptualization of bankruptcy. In Part II, we will explain the integrated process of bankruptcy rent-seeking, which incorporates transactional innovation, doctrinal innovation through litigation, and legislative lobbying that produces new law. We will also recount recent priorityjumping episodes, showing that every major creditor type has contested priority in recent decades. We situate these numerous priority jumps within our political economic framework. In Part III, we will explore the implications of breaking priority, conceptualizing the findings from Part II. Bankruptcy, rather than just effecting a contractarian creditors' bargain, is a rent-seeking process, one with deep and wide inefficiencies. Lastly, we will conclude. Creditors regularly attempt to break bankruptcy priority, and they often succeed. Breaking priority, reacting to the break, and counterattacking to restore a lost priority are all central features of modern bankruptcy practice. Without understanding the bankruptcy rent-seeking, priority-jumping process, we cannot fully understand or reform corporate reorganization to make it as efficient and as fair as possible.

\section{BASIC PRIORITY}

\section{A. The Bankruptcy Code's Basics}

The Bankruptcy Code's core principle is that distribution conforms to predetermined statutory and contractual priorities, with creditor equality within each priority class. ${ }^{29}$ Creditors cannot jump out of their class to obtain more value; they receive payment only after higher-ranking creditors are paid. The Code formally defers to state law priorities. For example, secured creditors' state-created priority allows them to be paid out of their state-based property interest in their collateral, to the exclusion of the debtor's unsecured creditors. ${ }^{30}$ Other creditors may agree by con-

\footnotetext{
${ }^{29}$ See Am. United Mut. Life Ins. Co. v. City of Avon Park, 311 U.S. 138, 147 (1940) (stating that "a [class] composition would not be confirmed where one creditor was obtaining some special favor or inducement not accorded the others, whether that consideration moved from the debtor or from another").

${ }^{30} 11$ U.S.C. $\S 506$ (2006).
} 
tract to be paid only after more senior creditors are fully paid. ${ }^{31}$ These subordination arrangements are common. Bankruptcy-specific rules prioritize favored creditors, such as tax authorities and employees claiming unpaid back wages, ${ }^{32}$ as well as offering priority to the post-bankruptcy suppliers of credit, goods, and services necessary to rehabilitate the debtor. $^{33}$ As bankruptcy distribution moves down the priority ladder, it eventually reaches the first unfortunate class that does not receive full payment; creditors in this class share proportionately in the value remaining, ${ }^{34}$ and lower priority classes receive nothing.

Section 1129(b) enacts these priority concepts, embodying the absolute priority rule. A creditor class that is not paid in full under a plan is entitled to have the judge rule that no lower-ranking claimant or equity interest may be paid a dime, ${ }^{35}$ and that no similarly situated creditor may be paid proportionately more. ${ }^{36}$ The bankruptcy judge is barred from confirming a proposed plan that violates either priority feature over the objection of the not-paid-in-full creditor class. ${ }^{37}$

Conceptually, this statutory structure is unexceptional. The Bankruptcy Code crisply and clearly sets up this priority scheme and the proportionate sharing of insufficient assets. ${ }^{38}$ Creditors in a Chapter 11 proceeding understand the priority ladder and come to terms with one another, resolving and compromising contractual and situational ambiguities and cross-claims to present a plan of reorganization for the bankruptcy judge to approve. ${ }^{39}$ If claimants cannot agree on the facts, terms,

${ }^{31}$ Id. § 510(a).

32 Id. § 507(a).

${ }^{33}$ Id. $\S \S 364,503$.

${ }^{34}$ Id. §§ 507(a), 1129(a).

${ }^{35}$ The statute's formal language is:

[T] he court . . . shall confirm the plan [over the objection of a creditor only] if the plan does not discriminate unfairly, and ... (i) ... the plan provides that each [dissenting creditor] receive or retain ... property of a value ... equal to the allowed amount of such claim; or (ii) [all] junior[s to the dissenting creditor] will not receive or retain ... any property ....

Id. § 1129(b). The bar to the reorganization plan “discriminat[ing] unfairly” gets its content elsewhere. It requires that incompletely compensated creditors either consent or have their claims paid ratably with similarly situated creditors. H.R. Rep. No. 95-595, at 415-18 (1977), reprinted in 1978 U.S.C.C.A.N. 5963, 6371-74.

${ }^{36} 11$ U.S.C. § 1129(b) (2006) (plan cannot discriminate unfairly); H.R. Rep. No. 95-595, at $415-18$.

${ }^{37} 11$ U.S.C. $\S 1129$ (a) (2006).

${ }^{38}$ Id. §§ 726, 1129.

${ }^{39}$ See id. §§ 1126, 1129(a)(8). 
or validity of the pre-bankruptcy priorities, the court resolves the ambiguities. If the proposed plan accords with the priority principle, with ratable sharing of losses among similarly situated creditors, then the bankruptcy judge approves the plan, cramming it down on any recalcitrant creditors who object to a plan that accords them their appropriate priority. Indeed, policymakers see bankruptcy priority as fundamental to sound business, with bankruptcy's fundamental goal being to "[e]stablish[] a single, clear hierarchy of payments." 40 This clear hierarchy is needed to facilitate a rapid reorganization of the failed firm in bankruptcy, as well as to facilitate smooth financing outside bankruptcy, by telling creditors in advance how the too-small pie will be divided if the firm cannot pay all of its financiers.

The contractarian principles at the foundation of absolute priority, hence, are simple.

\section{B. Some Code Refinements}

The Code articulates priority-related refinements beyond the basic rule of absolute priority. For example, for secured creditors, a mechanism is needed to ascertain whether their security is good; ${ }^{41}$ the court must value the security in close cases. For new post-bankruptcy lenders to the cash-starved enterprise, their priority must be established. (They rank, with some exceptions, prior to all pre-existing creditors. ${ }^{42}$ ) Similarly, post-bankruptcy suppliers would hesitate to supply needed services, raw materials, or machinery unless they are assured of payment. The Code offers such assurance. ${ }^{43}$ Specialized provisions govern the priorities for pension claims and mass tort claims. ${ }^{44}$

With these refinements, then, the Code effects a largely contractarian structure of claim priority.

Bankruptcy can thus be seen as a set of fixed priority rules into which creditors organize themselves. Most organize themselves via contract;

\footnotetext{
${ }^{40}$ Elena Cirmizi et al., The Challenges of Bankruptcy Reform, 27 World Bank Res. Observer 185, 188-89 (2012) (emphasis omitted); cf. 1 Max Weber, Economy and Society 43, 327-29, 336-37 (Guenther Roth \& Claus Wittich eds., Ephraim Fishcoff et al. trans., 1978) (noting that commerce depends on uniform, stable rules and standards).

${ }^{41} 11$ U.S.C. $\S 506$ (2006).

${ }^{42}$ Id. $\S \S 364,503,507$. To the cognoscenti, these are the DIP (for debtor-in-possession) lender provisions.

${ }^{43}$ Id. $\S \S 503(b), 507(a)$.

${ }^{44}$ Id. §§ 524(g), 1113, 1114.
} 
statute accords priority to a few, typically noncontracting, parties like tax authorities and tort claimants. Once organized, the players take on their assigned risks, and if the enterprise suffers, their pre-set priorities determine their distributions and losses in the ensuing bankruptcy.

\section{PRIORITY JUMPING AND ITS POLITICAL ECONOMY}

The basic priority structure detailed above is conventionally viewed as fixed and static. We now counter that view, showing priority to be very much in flux. It is hard to find a basic priority rule that has not been pressured in recent decades, with many being altered or replaced. We do not evaluate the efficiency of any priority jump in this Part-an issue we will take up in Part III. Instead, we demonstrate that priority jumping is widespread, and we locate priority jumps within a general political economy framework. We recount recent priority jumps to support our claim that priority jumping is an important facet of bankruptcy's normal science. ${ }^{45}$ Bankruptcy reorganization should be characterized as a rentseeking process as much as a contractual, financial process. The latter facet is now well understood; the former is not yet even part of the discussion.

\section{A. An Integrated Process of Bankruptcy Rent-Seeking}

Priority jumping costs something to creditors who pursue it. ${ }^{46}$ They hire expensive attorneys to design complex private arrangements for bankruptcy proofing - for example, special purpose vehicles (“SPVs”), which are elaborately constructed contractual priority jumps-and rollup debtor-in-possession ("DIP”) loans, through which a creditor has its nonpriority pre-bankruptcy loans rolled into prioritized post-bankruptcy loans. Creditors pay attorneys to argue for the doctrinal changes that bring about court-created priority jumps. And creditors pay to lobby

\footnotetext{
${ }^{45}$ For brevity's sake, we relegate further examples of priority jumping to the Appendix.

${ }^{46}$ In the efficiency-oriented analysis, these monopolies transfer value from consumers to producers, and they reduce overall social value because, to get that transfer, the monopolist must reduce production below what it could produce profitably and raise price beyond what it really needs to charge. That lost production is the social cost of monopoly, in the traditional rendition. See Tim Hazledine, Oligopoly and Rent-seeking: Cowling and Mueller Revisited, in Competition, Monopoly and Corporate Governance: Essays in Honour of Keith Cowling 141 (Michael Waterson ed., 2003); Keith Cowling \& Dennis C. Mueller, The Social Costs of Monopoly Power, 88 Econ. J. 727, 744-46 (1978); Posner, supra note 28, at 807; Tullock, supra note 28, at 228.
} 
Congress when these other approaches fail. We can think of these three mechanisms - innovative transactions, doctrinal mutation, and legislative lobbying — as a single integrated rent-seeking process. The process is not unique to bankruptcy, but it is not accorded the weight and analysis for bankruptcy that it receives elsewhere.

Rent-seeking via priority jumping is typically socially costly, as it is in other contexts, such as monopolization. Efficient competitors can sometimes capture an entire market and monopolize it, because no other competitor can provide as good a product. But inefficient competitors can monopolize a market as well by lobbying legislatures for exclusive privileges. Examples abound, from the trading privileges of the East India Trading Company of long ago to the licensing privileges in telecommunications of recent decades. The costs of monopolies include more than just the pricing, production, and resource allocation distortions they cause. When multiple competitors see potential monopoly profits, they will invest in mechanisms to obtain and preserve themlobbying, excessive price wars, and so on. These costs are also social costs of monopoly.

Transactional innovation can be the cheapest way to pursue a priority jump. If a new type of credit transaction accords priority to the lender in a way that the borrower's preexisting creditors had not expected, then it is priority jumping. Existing creditors suffer a loss as they bear more risk with no commensurate price adjustment. The new lender (and often the firm's owners) transfers value from the older creditors to itself.

Crafting a new transactional structure is likely to be cheap relative to litigating or lobbying for a jump. If the transactional adjustment "takes" and is left unchallenged, the priority-seeker wins. If the priority seeker's innovation is challenged, then the priority seeker can seek validation in court. If successful, the priority-seeking creditor jumps ahead of other creditors. For example, a weak pre-bankruptcy loan might not be paid in full unless it is rolled up into a post-petition, highly prioritized debtorin-possession loan. Creditors that persuade courts to permit roll-ups jump their priority. ${ }^{47}$

Bankruptcy litigation may be a messy process, however, in terms of exploring and establishing (or opposing) new priority jumps. Losers

\footnotetext{
${ }^{47}$ See infra Subsection II.B.1.
} 
rarely appeal from bankruptcy court decisions, ${ }^{48}$ so that different bankruptcy courts may have differing views about the validity of particular attempted priority jumps. Working out the differences takes time and resources in litigation, given the dearth of appeals that might offer doctrinal clarity.

When transactional innovation and litigation fail in delivering or defeating priority jumps with sufficient clarity for the combatants, oldfashioned legislative or regulatory lobbying may hold promise for priority jumping. Lobbying for special treatment is common in bankruptcy legislation. For example, multiple specific exemptions from the Code's automatic stay have been enacted. ${ }^{49}$ Legislative action for repo and derivatives transactions offers another major example. In the 1980s, financial creditors sought super-priority for repo financing, as well as exemption from the bankruptcy stay and the other inconveniences that secured lenders face. ${ }^{50}$ They characterized their short-term repo loans as sales of securities (which they would repurchase the following day). ${ }^{51}$ If the transaction were deemed a true sale-though functionally, it was a loan - then the lender would enjoy priority and other advantages greater

\footnotetext{
${ }^{48}$ Daniel J. Bussel, Power, Authority, and Precedent in Interpreting the Bankruptcy Code, 41 UCLA L. Rev. 1063, 1091-92 (1994); David A. Levin, Comment, Precedent and the Assertion of Bankruptcy Court Autonomy: Efficient or Arrogant?, 12 Bankr. Dev. J. 185, 20506 (1995). The Code makes many bankruptcy court determinations effectively unappealable, in that once the underlying transaction is approved by the bankruptcy court, the transaction will not be overturned even if the appeal succeeds. See, e.g., 11 U.S.C. §§ 363(m), 364(e) (2006). Losers need to get the courts to stay implementation of the bankruptcy ruling while they appeal, usually on an expedited basis. The appellate courts may shrink from issuing rapid decisions in a highly-pressured atmosphere, when the courts would have little time to study the approved transaction.

${ }^{49}$ See, e.g., 11 U.S.C. $\S 1110$ (2006) (automatic stay does not apply to lessors' or purchase-money lenders' efforts to retake aircraft equipment); id. § 362(b)(3) (automatic stay does not apply to efforts to perfect or maintain perfection of security interests in real property); id. § 362(b)(10) (automatic stay does not apply to lessor's efforts to reclaim nonresidential real property after expiration of lease); id. §§ 362(b)(20)-(21) (automatic stay does not protect real property from debtor engaging in serial filings); id. § 362(d)(4) (court may lift automatic stay for creditor secured by interest in real property if, after notice and hearing, court finds filing of petition was designed to delay, hinder, or defraud creditors); id. § 365(n) (licensee of debtor's intellectual property may retain its rights under contract with debtorlicensor, even if debtor rejects contract).

${ }^{50}$ See id. §§ 362(b)(17), 362(b)(27), 560 (derivative and repo counterparties may liquidate collateral in their possession); id. §§546(g), 546(j) (exemption from preference rules); id. $\S \S 546(\mathrm{~g}), 546(\mathrm{j})$ (exemption from constructive fraudulent conveyance liability); id. §§ 555, 559-561 (exemption from debtor’s § 365 option to affirm or reject executory contracts).

${ }^{51}$ See Jeanne L. Schroeder, Repo Madness: The Characterization of Repurchase Agreements Under the Bankruptcy Code and the U.C.C., 46 Syracuse L. Rev. 999, 1005 (1996).
} 
than conventional secured lenders. Attempts at cheap transactional changes came first, but early courts held the transaction to be nothing more than a secured loan. ${ }^{52}$ Having lost too much of the rent-seeking litigation, the financial players - already organized and influential because financial regulation is deeply imbued with rent-seeking - turned to Congress for their priority, which they obtained.

Legislative rent-seeking is immediately familiar to those who study financial market regulation. Banks seek to influence rules on mortgage lending or capital requirements or derivatives trading. ${ }^{53}$ Investment advisers, hedge funds, and broker-dealers all expend resources trying to affect the contours of their regulatory constraints. ${ }^{54}$ They seek these benefits from Congress and regulatory agencies. Even closer to corporate bankruptcy in this rent-seeking dimension is corporate lawmaking, where we now understand rent-seeking to be integral. In the last decade's reform of shareholder voting, for example, different groups sought favor from different legislative environments: Public pensions and funds sought privileged access to the shareholder voting machinery through administrative channels, ${ }^{55}$ and managers pursued their most friendly state legislature for a shareholder voting environment congenial to them. ${ }^{56}$

We elaborate these themes through concrete examples in the following two sections. In Section B we will discuss the first two rent-seeking channels, examining several major and minor transactional priority jumps that occurred prior to the financial crisis, as well as related litigation in some cases that affirmed, refined, or rejected transactional inno-

\footnotetext{
${ }^{52}$ Lombard-Wall Inc. v. Bankers Trust Co. (In re Lombard-Wall Inc.), 23 B.R. 165, 166 (Bankr. S.D.N.Y. 1982).

${ }^{53}$ See Richard L. Hasen, Lobbying, Rent-Seeking, and the Constitution, 64 Stan. L. Rev. 191, 233-34 (2012); Victoria McGrane, New Capital Rules Likely for Banks, Wall St. J., Sept. 27, 2011, at C1; Peter Eavis, Parsing Bank Lobbyists’ Dire Warnings on Derivatives Rules, N.Y. Times DealBook (May 1, 2012, 12:54 PM), http://dealbook.nytimes.com/2012/ 05/01/parsing-bank-lobbyists-dire-warnings-on-derivatives-rules; Christine Harper et al., Wall Street Stealth Lobby Defends \$35 Billion Derivatives Haul, Bloomberg (Aug. 30, 2009, 7:01 PM), http://www.bloomberg.com/apps/news?pid=newsarchive\&sid=agFM_w6e2i00.

${ }^{54}$ See Ctr. for Responsive Politics, Lobbying: Securities and Investment Industry Profile 2012, http://www.opensecrets.org/lobby/indusclient.php?id=F07\&year=2012; Ben Protess, Wall Street Continues to Spend Big on Lobbying, N.Y. Times DealBook (Aug. 1, 2011, 2:33 PM), http://dealbook.nytimes.com/2011/08/01/wall-street-continues-to-spend-big-on-lobbying.

${ }^{55}$ Joseph A. Grundfest, The SEC’s Proposed Proxy Access Rules: Politics, Economics, and the Law, 65 Bus. Law. 361, 365 (2010).

${ }_{56}$ Mark J. Roe, The Corporate Shareholder's Vote and Its Political Economy, in Delaware and in Washington, 2 Harv. Bus. L. Rev. 1, 4 (2012).
} 
vations. In Section C, we will discuss rent-seeking in Congress before the financial crisis, focusing on the special bankruptcy treatment for repurchase financing and derivatives.

\section{B. Transactional Innovation and Litigation}

Four important priority jumps illustrate the interplay of transactional strategy and litigation challenge in the rough and tumble of bankruptcy rent-seeking - the DIP lender's roll-up priority, critical-vendor priority, unsecured-creditor priority in sales of entire firms under Section 363 of the Code, and priority for structured-finance transactions. Each has been important to bankruptcy practitioners, bankruptcy analysts, and the bankruptcy process. We describe these priority jumps and the rentseeking processes through which they were created.

\section{The DIP Lender's Priority Jump}

Bankrupt companies have typically run out of cash by the time they file for reorganization in Chapter 11. To keep their operations going-to meet the next week's payroll — the company usually needs a rapid, major infusion of fresh cash. But those with cash are wary of lending to the bankrupt, especially if they would have to compete with pre-existing creditors for repayment. The Bankruptcy Code facilitates these new debtor-in-possession loans by requiring that they be repaid before prebankruptcy debt. ${ }^{57}$ (The debtor-in-possession is the bankrupt company, after it has filed for bankruptcy; the debtor-in-possession lender is the financier who provides the bankrupt with new cash to operate.) In these terms, such priority for the new lender is unexceptional. It is not priority jumping, but a practice of long standing: New credit often commands special priority. ${ }^{58}$

\footnotetext{
${ }^{57} 11$ U.S.C. $\S \S 364,1129$ (a)(9) (2006). This is not to say that these loans' priority is without controversy. If the bankrupt debtor wastes the cash and the new lender is repaid anyway, this priority process wastes social value and is paid for by the pre-bankruptcy creditors. Beyond ordinary priority for the new lender is the extent of its priority. The Code anticipated that in unusual circumstances, the new lender's priority could extend into the assets of preexisting secured creditors. See id. § 364(d). What was once unusual has become more commonplace in recent years.

${ }^{58}$ See, e.g., id. § 726(b) (prioritizing the administrative expenses incurred in a Chapter 7 case over the administrative expenses from any prior Chapter 11, 12, or 13 proceeding that converted to the Chapter 7 case).
} 
Sometimes the post-bankruptcy lender seeks and obtains more than its basic priority entitlement. ${ }^{59}$ Often it had already lent to the firm before the bankruptcy and sees weaknesses in its pre-bankruptcy loan that put that loan at risk-a potential for collateral inadequacy, for example, or another legal challenge to the claimed fully secured status of the prebankruptcy loan. This lender offers additional credit via the postbankruptcy DIP loan, but insists that its potentially problematic prebankruptcy loan be rolled up into-essentially paid off by - the new, prioritized DIP loan. ${ }^{60}$ At the time of filing, the company needs, say, $\$ 100$ million in cash. The lender already has \$50 million outstanding on its weak pre-bankruptcy loan, so the lender agrees to a fresh loan of $\$ 150$ million, all of it advantaged by the super-priority sections of the Code for DIP loans. The parties understand (or the contract requires) that the debtor will immediately draw $\$ 50$ million of the prioritized DIP loan to pay off the weak $\$ 50$ million pre-bankruptcy loan. By extinguishing the pre-bankruptcy loan in this way, the payoff "rolls up" the \$50 million amount into the highly prioritized DIP loan, effectively converting the DIP lender's (likely) undersecured pre-bankruptcy loan into a fully secured postpetition claim. This is priority jumping.

In theory, the old loan may be fully secured and therefore would have been paid in full anyway. ${ }^{61}$ For that sure-to-be-repaid loan, the roll-up is simply a matter of convenience, allowing the bankrupt debtor and the creditor to manage a single lending facility. On the other hand, if the security is weak, the deficiency ought to have become an ordinary unsecured loan, ${ }^{62}$ which is rarely repaid in full. But in a roll-up,

\footnotetext{
${ }^{59}$ Resolution Trust Corp. v. Official Unsecured Creditors Comm. (In re Defender Drug Stores), 145 B.R. 312, 316 (B.A.P. 9th Cir. 1992) ("Bankruptcy courts . . have regularly authorized postpetition financing arrangements containing lender incentives beyond the explicit priorities and liens specified in section 364.”); George W. Kuney, Hijacking Chapter 11, 21 Emory Bankr. Dev. J. 19, 57 n.178 (2004) ("Presumably, the validity of the remedies relies on the bankruptcy judge's powers of equity arising inherently and from $\S 105$ (a) of the Bankruptcy Code. Section 105(a) states that '[t]he court may issue any order, process, or judgment that is necessary or appropriate to carry out the provisions of [Title 11] ....”' (alteration in original) (quoting 11 U.S.C. § 105(a) (2000))).

${ }^{60}$ Daniel J. Bussel \& Kenneth N. Klee, Recalibrating Consent in Bankruptcy, 83 Am. Bankr. L.J. 663, 707 n.209 (2009) (“'Roll-ups' are arrangements whereby prepetition secured claims are converted to postpetition secured claims. This conversion is advantageous to the secured creditor primarily because prepetition claims may be subject to avoidance and restructuring, whereas postpetition claims, invariably, are not ....”).

${ }^{61}$ See 11 U.S.C. §§ 506, 1123 (2006).

${ }^{62}$ See id. $§ 506$.
} 
the bankruptcy process often does not examine the old collateral's adequacy and the old loan's bona fides carefully. ${ }^{63}$ Sometimes the process doesn't examine them at all. There is a priority jump to the extent some portion of the pre-bankruptcy loan would not otherwise have been paid. Figure 1 illustrates.

\section{Figure 1: Comparing DIP Loans With and Without Roll-up}

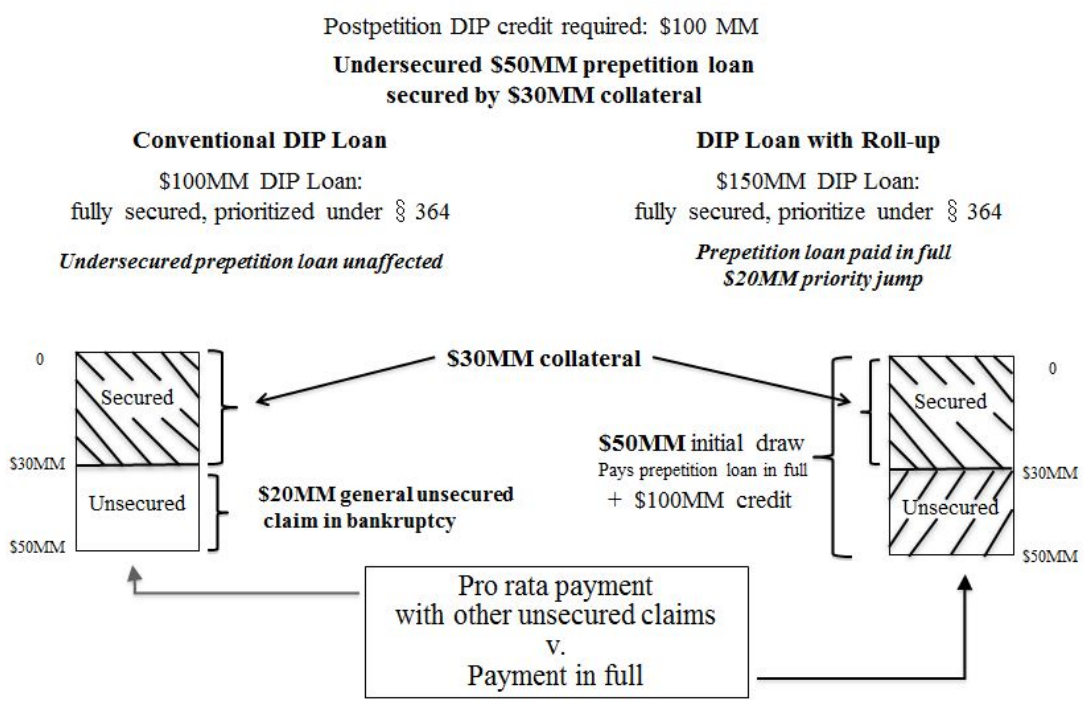

Figure 1 compares DIP loans with and without a roll-up. The roll-up feature here alters priorities and distribution. The lender's prepetition security is insufficient to cover the prepetition loan value, with the insufficiency at \$20 million. Without a roll-up, under Section 506, the lender would have a \$30 million secured claim, which would typically be paid in full, and a \$20 million unsecured claim, which would only be paid proportionately with other unsecured creditors. It would rarely be paid in full, because the bankrupt firm usually lacks enough value to pay all of its creditors. However, the extent and existence of

\footnotetext{
63 James J. White, Death and Resurrection of Secured Credit, 12 Am. Bankr. Inst. L. Rev. 139, 182-83 (2004) ("Some rollups are noisy. In some cases the DIP lender pays off the existing loan in full. That payment is treated as the first advance on the post-petition secured loan ... . No one could miss that event.” (citation omitted)); see also Craig R. Bucki, Cracking the Code: The Legal Authority Behind Extrastatutory Debtor-In-Possession Financing Mechanisms and Their Prospects for Survival, 2005 Colum. Bus. L. Rev. 357, 372; Marcia L. Goldstein et al., Current Issues in Debtor in Possession Financing (Chapter 11 Business Reoganizations, ALI-ABA Course of Study) SJ082 ALI-ABA 29, 40 (2004) (noting that courts have enforced roll-ups “[d]espite judicial reservations” and limited clarification about their enforceability).
} 
the shortfall are uncertain and not visible to the court without an extensive valuation process. With the roll-up, the debtor borrows \$150 million from the same lender after the debtor files for bankruptcy. Fifty million of the $\$ 150$ million DIP loan is used to pay off the entirety of debtor's pre-bankruptcy loan, as though it were fully secured. This process jumps the lender's shortfall up from partially-paid to fully-paid status.

Roll-up financing nicely illustrates both transactional innovation to jump priority and the litigation that often follows. Roll-up priority evolved through an iterative hit-and-miss approach involving both transactional innovation and spurts of litigation. Before roll-ups, DIP lenders tried cross-collateralization, a more transparent way of pursuing secured status for undersecured pre-bankruptcy loans. With crosscollateralization, the DIP lender insisted as part of its DIP financing deal that the collateral securing the DIP loan would also secure its prebankruptcy loan. To the extent the DIP loan collateral included assets that did not already secure the pre-bankruptcy loan, crosscollateralization gave extra collateral to the old pre-bankruptcy loan. Once in bankruptcy, however, debtors are typically not freely permitted to give new collateral for pre-bankruptcy loans.

It was no surprise that unsecured creditors, disadvantaged by crosscollateralization, challenged its permissibility, and cross-collateralization suffered a checkered fate in the courts. Though a few lower courts reluctantly upheld DIP financing cross-collateralized with the lender's prebankruptcy loans, ${ }^{64}$ two important court of appeals decisions found it impermissible. ${ }^{65}$

Once it became clear to lenders and their lawyers that bankruptcy courts would not regularly countenance cross-collateralization, these lenders innovated with the roll-up structure. The roll-up device then had to be litigated as well, with junior creditors objecting to their further subordination below the DIP lender's pre-bankruptcy deficiency

\footnotetext{
${ }^{64}$ See In re Roblin Indus., 52 B.R. 241, 246-47 (Bankr. W.D.N.Y. 1985); In re Vanguard Diversified, Inc., 31 B.R. 364, 367 (Bankr. E.D.N.Y. 1983); Borne Chem. Co. v. Lincoln First Commercial Corp. (In re Borne Chem. Co.), 9 B.R. 263, 270 (Bankr. D.N.J. 1981).

${ }^{65}$ See Shapiro v. Saybrook Mfg. Co. (In re Saybrook Mfg. Co.), 963 F.2d 1490, 1494-95 (11th Cir. 1992) (holding cross-collateralization impermissible under the Bankruptcy Code because it is not authorized under $\S 364$ and directly conflicts with the established Code priority scheme); Otte v. Mfrs. Hanover Commercial Corp. (In re Texlon Corp.), 596 F.2d 1092, 1097-98 (2d Cir. 1979) (holding cross-collateralization impermissible under the Bankruptcy Act, which preceded the current Bankruptcy Code).
} 
claim. ${ }^{66}$ Through this series of innovations and court contests, both proponents and objectors hired and paid their lawyers, creating a sort of arms race of priority jumping and defense. ${ }^{67}$

Finally, even after roll-up priority became routinely granted in the courts, other creditors countered with their own priority jumping innovation. As we will discuss below, SPV lending emerged to enable lenders to trump the roll-up and other special priorities that DIP lenders enjoy. ${ }^{68}$ This evolution of changing priorities illustrates the leapfrogging, rentseeking process and attendant costs that priority jumping may trigger. Lawyers for would-be SPV lenders produced a transactional innovation that sidestepped some of the hard-won priority gains DIP lenders with prebankruptcy loans had achieved through their own lawyers' creative transactional and litigation strategies.

And as with arms races generally, pursuit by one group will typically trigger defensive measures by opposing groups, affecting their relative standing but perhaps not generating any transactional efficiencies.

\section{The Critical Vendor's Priority Jump}

Suppliers often ship inventory and raw materials to their customers on credit - with payment due, say, at the end of the month. If the customer files for bankruptcy before it pays the supplier, the unpaid supplier has a general unsecured claim against the bankrupt, which is entitled to no

\footnotetext{
${ }^{66}$ The United States Bankruptcy Court for the District of Delaware permits roll-ups, but only where they are identified in the motion to approve financing and are justified. Del. Bankr. L.R. 4001-2(a)(i). The Southern District of New York requires a hearing to approve a roll-up. See, e.g., S.D.N.Y. LBR 4001-2. Other courts permit them but are skeptical. See Transamerica Commercial Fin. Corp. v. Citibank (In re Sun Runner Marine), 945 F.2d 1089, 1095 (9th Cir. 1991) ("[T]he use of financing to pay a prepetition unsecured debt is to be used only in extreme cases.”); In re Equalnet Commc'ns Corp., 258 B.R. 368, 369, 371 (Bankr. S.D. Tex. 2000) (denying DIP financing that utilized roll-up but permitting certain prepetition claims to be paid during automatic stay).

${ }^{67}$ See Kevin M. Murphy et al., Why Is Rent-Seeking So Costly to Growth?, 83 Am. Econ. Rev. Papers \& Proceedings 409, 409 (1993).

${ }^{68}$ See infra Subsection II.B.4. A priming lien gives the new money DIP lender in bankruptcy a security interest in assets senior to any pre-existing liens on those assets. It is specifically authorized under $\S 364(\mathrm{~d})$ and is therefore not a priority jump for purposes of our analysis.
} 
special priority. ${ }^{69}$ It gets pro rata payment with other unsecured creditors, but no more than that. ${ }^{70}$

In recent years, however, the practice emerged of the debtor identifying a class of pre-bankruptcy vendors as critical to its continuing operations. It sought and often obtained court approval to pay those vendors' pre-bankruptcy claims in full in cash, as prioritized administrative expenses. ${ }^{71}$ This approval came early in the bankruptcy case to assure that these critical vendors would continue supplying the debtor. ${ }^{72}$ Conceptually, this prioritization often makes sense: the goodwill from paying employees or employee-like claimants (like the night-time cleaning service or the local electrician) in full should, if the business judgment is done well, benefit the bankrupt overall.

From that conceptual core, the critical vendor practice mushroomed, with critical vendor (and roll-up) orders disposing of major portions of estate value. ${ }^{73}$ In the bankruptcy of Kmart, for example, \$300 million of

\footnotetext{
${ }^{69}$ See 11 U.S.C. § 362(a) (2006); see also Mark A. McDermott, Critical Vendor and Related Orders: Kmart and the Bankruptcy Abuse Prevention and Consumer Protection Act of 2005, 14 Am. Bankr. Inst. L. Rev. 409, 409 (2006) (“A business that files a petition under chapter 11 of the Bankruptcy Code... generally may not make any payments or other distributions on account of pre-petition claims except pursuant to a plan of reorganization that has been confirmed by a bankruptcy court.”).

${ }^{70}$ Exceptions exist. Section 546(c) permits a seller to reclaim goods sold to an insolvent provided that the reclamation claim satisfies the Code's requirements. This right derives from the common law (later codified in U.C.C. § 2-702), which presumed that when the seller sold to an insolvent buyer, the buyer had concealed the insolvency, defrauding the seller. See, e.g., Conyers v. Ennis, 6 Fed. Cas. 377, 378 (D.R.I. 1821) (No. 3,149); Hall v. Naylor, 18 N.Y. 588, 589 (1859). Section 503(b)(9) of the Bankruptcy Code provides vendors with an administrative expense for the value of goods received by the debtor within the twenty days before the debtor's petition. Section 503(b)(9) is particularly advantageous to vendors because classifying vendors' claims as administrative expenses affords vendors full payment of the claim on the effective date of the plan, not a pro rata share of the claim's value. See 11 U.S.C. §§ 503(b)(9), 507(a)(2), 1129(a)(9)(A) (2006).

${ }^{71}$ See, e.g., In re Lehigh \& New Eng. Ry. Co., 657 F.2d 570, 581 (3d Cir. 1981) (authorizing payment to creditors under "necessity of payment" doctrine where payment "is in the interest of all parties ... [and] will facilitate the continuing operation of the [bankrupt]"); In re Just For Feet, Inc., 242 B.R. 821, 824 (D. Del. 1999); In re Wehrenberg, Inc., 260 B.R. 468, 469 (Bankr. E.D. Mo. 2001). See generally 2 Collier on Bankruptcy I 105.02[4][a] (Alan N. Resnick \& Henry J. Sommer eds., 16th ed. 2012) (1979).

72 The bankrupt can buy new supplies to keep the factory running, with the suppliers' new credit to the bankrupt entitled to priority over the pre-bankruptcy debts. See § 503(b).

${ }^{73}$ See Lynn M. LoPucki \& Christopher R. Mirick, Strategies for Creditors in Bankruptcy Proceedings $\S 10.03[\mathrm{E}]$, at 423 (4th ed. 2003) (“Although some courts have criticized distributions to prepetition creditors other than pursuant to a confirmed plan as being inconsistent with the Bankruptcy Code, these payments are increasingly being authorized early in the case ...." (citation omitted)).
} 
the debtor's \$2 billion DIP financing was ordered to be paid out in critical vendor payments just as the bankruptcy commenced. ${ }^{74}$ These early and substantial payouts disfavored other unsecured creditors and were difficult to appeal, coming so early in the case as they did and depending on factual judgments as to whether estate value was enhanced. ${ }^{75}$ It would also have been administratively difficult for an appellate court to order the recovery of these numerous small payments after the fact.

In Kmart, disfavored creditors appealed nevertheless, arguing that the critical vendor designation was too broad, involving too many ordinary suppliers. In the Kmart appeal, the U.S. Court of Appeals for the Seventh Circuit explained how critical vendor payments could, with difficulty, be consistent with the overall Bankruptcy Code structure. ${ }^{76}$ While no explicit statutory authority supports these payments, a bankruptcy court could authorize them if they enhanced the bankrupt's overall value, benefiting all creditors. If full payment to the cleaning service was necessary to induce it to continue dealing with the firm in bankruptcy, and if that continuity would enhance the value of the enterprise enough that the other creditors would come out ahead, then the payment could be justified as an appropriate expenditure of the debtor's assets under Section 363. ${ }^{77}$ But, the Seventh Circuit asked, how often could those conditions exist? ${ }^{78}$ Rational creditors understand sunk costs. If future sales to the bankrupt are profitable, the economically rational supplier will sell and ship, even if it lost money on pre-bankruptcy shipments. And if the supplier will not sell and ship, often the bankrupt can find alternative suppliers. So the instances in which a key supplier can stymie the bankrupt cannot be many. The bankruptcy court's job, said the Seventh Circuit, is to judge whether a proposed critical vendor payment

\footnotetext{
${ }^{74}$ In re Kmart Corp., 359 F.3d 866, 869 (7th Cir. 2004).

${ }^{75}$ See id. at 868 ("Bankruptcy Judge Sonderby entered a critical-vendors order just as Kmart proposed it, without notifying any disfavored creditors, without receiving any pertinent evidence (the record contains only some sketchy representations by counsel plus unhelpful testimony by Kmart's CEO, who could not speak for the vendors), and without making any finding of fact that the disfavored creditors would gain or come out even.”).

${ }^{76}$ Id. at $871-72$.

${ }^{77}$ See 11 U.S.C. § 363(b)(1) (2006). More famous for authorizing whole-firm sales in Chapter 11, § 363 also authorizes the debtor to use assets of the estate out of the ordinary course, upon court order.

${ }^{78}$ Kmart, 359 F.3d at 872-73.
} 
would enhance the remaining value of the estate enough to justify the payment. $^{79}$

In practice, few lower courts expend much energy making the judgments that the Seventh Circuit thought appropriate. Debtors ask that the old vendors be paid and courts approve those requests. ${ }^{80}$ If the overall balance supports the Seventh Circuit's approval prerequisite-that the bankrupt and its other creditors be benefited by more than the extra payment - the approval is justified priority jumping. Otherwise, it is unjustified. Either way, the new critical vendor institution in bankruptcyan important one for modern bankruptcy practice-constitutes priority jumping.

Although critical vendor payments were common when Kmart came down, Judge Easterbrook's opinion reminds us that doctrinal priority jumps may not be smoothly or easily countenanced. Opponents of priority jumps sometimes win. With that possibility, as well as circuit splits, one can easily imagine prolonged contestation of doctrinal priority jumps, a circumstance that may make resort to Congress an attractive strategy. Lobbied by trade creditors, Congress amended the Code in 2005 to give automatic administrative priority status to suppliers, whether or not "critical," who shipped any goods to the bankrupt within twenty days of its bankruptcy. ${ }^{81}$

\footnotetext{
${ }^{79}$ Id. at 874 (stating that classification and unequal treatment would be "proper only when the record shows that the classification would produce some benefit for the disfavored creditors").

${ }^{80}$ Joseph Gilday, “Critical” Error: Why Essential Vendor Payments Violate the Bankruptcy Code, 11 Am. Bankr. Inst. L. Rev. 411, 419 (2003) (“Generally courts approving a critical vendor motion leave it to the debtor to decide which of its aggressive vendors are important enough to justify payment. ... The definition of 'critical' differs from court to court, but it is usually amorphous.” (citations omitted)); McDermott, supra note 69, at 414-15 ("For years, there has been little attention paid by courts to the precise standard that a debtor was required to satisfy when seeking to honor pre-petition claims of essential creditors .... This approach has led to a stance towards critical vendor payments that can be relatively lenient.”); see also Mich. Bureau of Workers' Disability Comp. v. Chateaugay Corp. (In re Chateaugay Corp.), 80 B.R. 279, 287 (S.D.N.Y. 1987).

${ }^{81} 11$ U.S.C. § 503(b)(9) (2006). On trade creditors’ lobbying, see Bankruptcy Abuse Prevention and Consumer Protection Act of 2003, and the Need for Bankruptcy Reform: Hearing on H.R. 975 Before the Subcomm. on Commercial and Admin. Law of the H. Comm. on the Judiciary, 108th Cong. 45-47 (2003) (statement of Robin Schauseil, President, National Association of Credit Management); Elizabeth Warren \& Jay Lawrence Westbrook, The Law of Debtors and Creditors 467 (6th ed. 2009) (reporting that $\S$ 503(b)(9) resulted from "much lobbying from an association representing trade creditors").
} 


\section{The Section 363 Sale Priority Jump}

The Bankruptcy Code anticipated that creditors would bargain to consent to a bankruptcy plan that compromised statutory, conduct, and valuation uncertainties, and distributed value according to absolute priority. ${ }^{82}$ The Code contemplated that the debtor would sometimes sell assets - deteriorating inventory, shuttered factories, or even an ongoing operation that just did not fit the future of the bankrupt's downsized operations. Section 363 authorizes the sale of the debtor's assets.

As the merger market boomed in the late 1980s and 1990s, the practice of whole-firm bankruptcy sales arose. ${ }^{83}$ A buyer for the entire firm would be found and would make an offer. The court would then solicit competing bids to validate the first offer and would sell the firm at the completion of an auction. Having cashed out all its assets, the bankrupt firm would distribute the sale proceeds to its creditors in priority order. ${ }^{84}$

\section{a. Section 363 Sales and Market Valuation}

In principle, the whole-firm sale raises no priority issues. But putting a hard, market-determined figure on the firm's value preempts a valuation fight in court. The bankrupt is sold, the auction yields, say, \$50 million, and that is what the court distributes to the bankrupt's creditors, no more and no less. By contrast, the garden-variety reorganization without a sale generates no hard valuation to guide the distribution. If the court generously but mistakenly values the firm at $\$ 100$ million, more creditors are compensated in the reorganization than if the firm's value is accurately pegged at only $\$ 50$ million. Some creditors who would have been wiped out in a hard sale value of $\$ 50$ million could survive the reorganization, receiving some distribution in the reorganization with a court-determined value of $\$ 100$ million. ${ }^{85}$ Suppose senior and junior creditors are due $\$ 50$ million each. With the court’s mistakenly generous

\footnotetext{
${ }^{82}$ See 11 U.S.C. §§ 1126(f), 1129(a)(8) (2006).

${ }^{83}$ Lynn M. LoPucki, Courting Failure: How Competition for Big Cases Is Corrupting the Bankruptcy Courts 168-70 (2005).

${ }^{84}$ Id. LoPucki hypothesizes that the drafters of $\S 363$ thought of the sales that they were authorizing as transactions involving particular assets, not entire businesses. However, the text of $\S 363$ contains no limiting language to that effect.

${ }^{85}$ Moving from a tendency to overvalue relative to market values to a tendency to undervalue relative to market values thereby affects distribution and, in effect, priority. Walter J. Blum, The Law and Language of Corporate Reorganization, 17 U. Chi. L. Rev. 565, 570 (1950); Mark J. Roe, Bankruptcy and Debt: A New Model for Corporate Reorganization, 83 Colum. L. Rev. 527, 547-48 (1983).
} 
\$100 million valuation, juniors jump into the distributional queue to obtain $\$ 50$ million in nominal value-or one half of the true value of the firm. While priority was absolute in form, in practice it was frustrated.

Figure 2: Replacing Judicial Valuation with Market Valuation via a Section 363 Sale

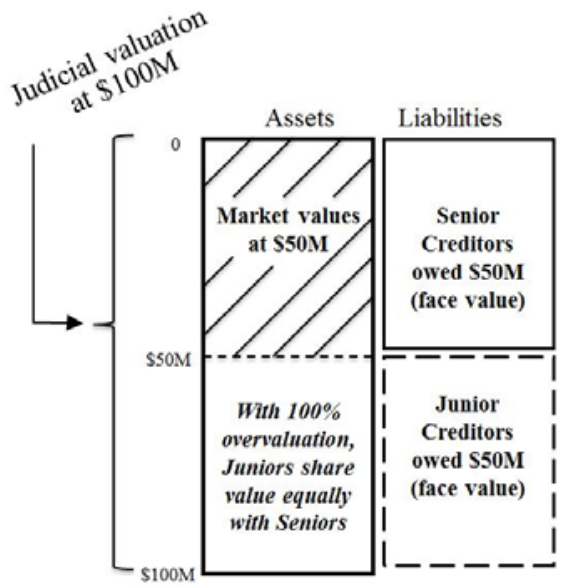

Judicial Over-Valuation Compared with Market Values

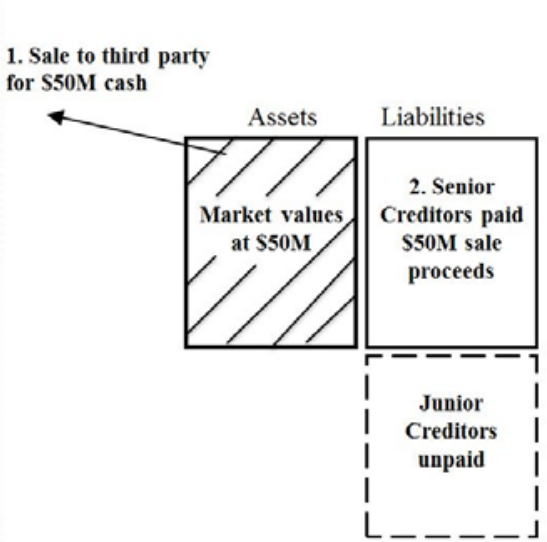

Market Valuation via Section 363 Sale to Third Party

In this Figure 2, the left balance sheet shows the firm with $\$ 100$ million of debt, divided equally between seniors and juniors. The shaded rectangle on the asset side shows the firm to be worth $\$ 50$ million. The longer rectangle, which includes the shaded rectangle on the asset side, shows a judicial over-valuation of the firm, at $\$ 100$ million. According to the conventional wisdom, overvaluation of firms is common. The over-valuation allows all creditors to share in the bankruptcy distribution, because in our example the court deems the firm to be worth $\$ 100$ million, allowing $\$ 100$ million of creditors to be compensated in the plan. If the compensation takes the form of stock of the reorganized debtor, it will be divided equally between the seniors and juniors. Each will have been deemed to be paid in full, but the actual value each receives would be only \$25 million, not the \$50 million each is owed. Juniors would thereby be over-compensated by $\$ 25$ million in market value, while seniors would be undercompensated by $\$ 25$ million in market value.

In the balance sheet on the right, the firm's operations are sold under Section 363 for $\$ 50$ million. That value is then distributed to pay the seniors in full, while juniors receive nothing. If the market sale more accurately values the firm's operations than the judicial valuation, then priority is better implemented in the Section 363 sale. Regardless of which is more accurate, the emergence of regular Section 363 sales has entailed a sharp reallocation of de facto priority 
and actual distribution to the extent that judicial valuation yielded assigned values materially larger than market valuations.

When judicial valuations were routine and Section 363-type sales rare, ${ }^{86}$ this overvaluation priority jump for junior creditors was not uncommon. The judiciary was generally thought to over-value the debtor firm, as compared to market values. The Section 363 sale thus alters priority by replacing elastic judicial valuation with hard-edged market valuation, jumping (perhaps legitimately) senior creditors and suppressing juniors, as compared to the status quo ante. Even if market valuation is no more accurate than judicial valuation, as long as it provides a systemically lower valuation, priority jumping is in play.

Section 363 has no overlay of priority embedded in it. Courts have, however, held that the section cannot be used to undermine the Code's basic priority rules, ${ }^{87}$ and the auction practice reduces the probability of priority deviation due to valuation inaccuracies or insider rigging of the sale. Even still, some commentators criticize the recent Chrysler reorganization on this issue, with the transaction structure and the weak auction process depriving the court of information as to whether priority was respected. ${ }^{88}$

Once in place, the Section 363 sale can itself become an area for further priority jumps, as analyzed next.

\section{b. Section 363 Sales and Assumed Debt}

The sale offers a way to reposition a firm's operations using a merger model, rather than the bargained-for, internal restructuring model that traditionally prevailed in Chapter 11 . The merger model makes intuitive

\footnotetext{
${ }^{86}$ Prior to the passage of the 1978 Code, judicial valuation in a large Chapter X reorganization was mandatory.

${ }^{87}$ See, e.g., Institutional Creditors of Cont'l Air Lines v. Cont'l Airlines (In re Cont'l Air Lines), 780 F.2d 1223, 1226 (5th Cir. 1986); Comm. of Equity Sec. Holders v. Lionel Corp. (In re the Lionel Corp.), 722 F.2d 1063, 1066 (2d Cir. 1983); Pension Benefit Guar. Corp. v. Braniff Airways (In re Braniff Airways), 700 F.2d 935, 939-40 (5th Cir. 1983); Ohio Dept. of Taxation v. Swallen's, Inc. (In re Swallen’s, Inc.), 269 B.R. 634, 637-38 (B.A.P. 6th Cir. 2001); In re Crowthers McCall Pattern, Inc., 114 B.R. 877, 885 (Bankr. S.D.N.Y. 1990); In re Lion Capital Grp., 49 B.R. 163, 177 (Bankr. S.D.N.Y. 1985).

${ }^{88}$ See Mark J. Roe \& David Skeel, Assessing the Chrysler Bankruptcy, 108 Mich. L. Rev. 727, 767-71 (2010); see also Barry E. Adler, A Reassessment of Bankruptcy Reorganization after Chrysler and General Motors, 18 Am. Bankr. Inst. L. Rev. 305, 315 (2010); Douglas G. Baird, Lessons from the Automobile Reorganizations, 4 J. Legal Analysis 271, 280-81 (2012).
} 
sense. Failed firms in declining industries should perhaps contract; other firms may need a managerial shake-up. Merger offers one important method of accomplishing these goals. However, to the extent that the purchaser assumes some but not all of the debtor's pre-existing liabilities as part consideration for the sale, creditors holding those claims typically enjoy a priority jump. The purchasing entity typically has an operational value exceeding the amount of the debt it assumes, while the consideration flowing into the bankruptcy estate is insufficient to pay the old creditors in full. The consequence is that the non-assumed creditors are not paid in full, but the assumed creditors are. Figure 3 illustrates.

Figure 3: Section 363 Sale with Some Liabilities Assumed, Some Left Behind

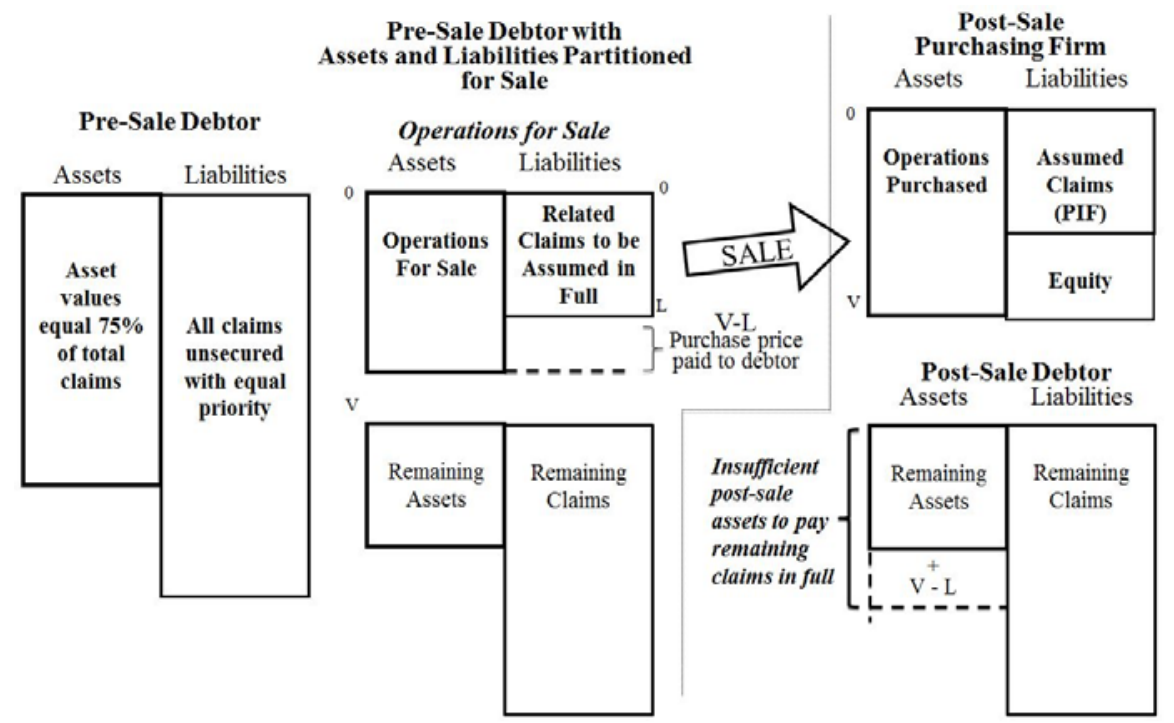

Figure 3 illustrates a Section 363 sale with some of the debtor's prebankruptcy liabilities assumed by the purchaser. The firm in Figure 3 lacks sufficient value to pay its unsecured claims in full. Proportionately, they would be paid seventy-five percent of the value of their claim, as represented in the leftmost balance sheet. In the middle balance sheet, the assets and claims are divided for sale, with only some claims to be assumed by the purchaser and expected to be paid in full. In the right-most balance sheet, the full-payment of the assumed claims is illustrated on the top balance sheet. The bottom balance sheet shows that the Post-Sale Debtor has insufficient assets to pay the remaining claims in full. 
An analysis similar to the Seventh Circuit's critical vendor analysis could justify some sale-plus-debt-assumption transactions. ${ }^{89}$ If the transferred creditor provides special value that enhances the new firm's operations, then as long as the enhanced value exceeds the size of the priority jump, the left-behind creditors receive no less than their priority entitlements. But if the enhanced value is insufficient, there is an unjustified priority jump.

\section{The SPV and Structured Finance Jump}

Structured finance offers an important instance of transactional innovation for priority jumping. It has become a major component of corporate finance. With structured finance, lenders wary of the debtor's overall operations and obligations can lend to an isolated facility-a special purpose vehicle - that is structured to always be solvent. ${ }^{90}$ Think of a borrower firm's operations as generating accounts receivable when the firm ships product to customers. In doing its credit analysis and assessing its repayment prospects, the prospective lender may wish to avoid the firm's operational risks. Instead, it may wish to lend simply on the strength of the firm's accounts receivable-a common arrangement.

But even a conventional loan on the accounts receivable carries nonpayment risk that the lender would like to avoid, and that the borrower firm would like to avoid having to compensate the lender for running. If the debtor goes bankrupt, the Bankruptcy Code automatically enjoins the lender from collecting on its loan (called, in bankruptcy vocabulary, "the automatic stay"). ${ }^{91}$ If the lender thinks that its collateral is deteriorating in value, it can ask the court for relief, and the court is required to either adequately protect the lender or lift the stay. ${ }^{92}$ Even though courts are usually solicitous of the secured creditor's request, the creditor may wish to avoid both the risk of judicial error and the inconvenience of having to go to court. It would like to seize and sell the security immediately. If it cannot do so, not only does it risk an uncompensated decline

\footnotetext{
${ }^{89}$ See Kmart, 359 F.3d at 868.

${ }^{90}$ See generally John A. Pearce II \& Ilya A. Lipin, Special Purpose Vehicles in Bankruptcy Litigation, 40 Hofstra L. Rev. 177, 182-85 (2011).

${ }^{91}$ See 11 U.S.C. $\S 362$ (2006).

${ }^{92}$ See id. § 362(d).
} 
in the value of its collateral, but it does not necessarily get interest paid during the delay in obtaining value. ${ }^{93}$

The secured creditor would also like to avoid having its priority jumped by a new-money lender in the firm's bankruptcy. ${ }^{94}$ If the debtor cannot repay the new, highly-prioritized DIP loan, there are multiple scenarios in which the pre-bankruptcy lender with a security interest in the accounts receivable could lose value.

Figure 4: Before and After SPV Transaction

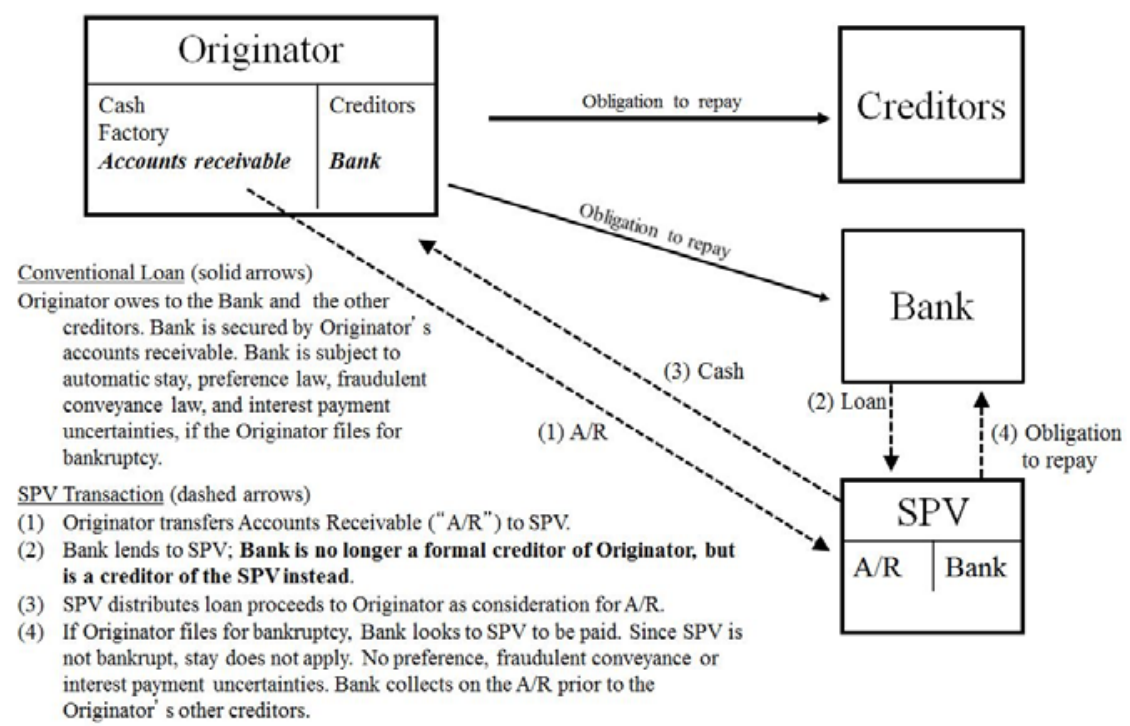

Figure 4 illustrates a common special purpose vehicle setup. Without an SPV, the firm's creditors share proportionately in all of the assets of the Originator. If creditors cannot obtain sufficient value from the cash and factory to be repaid in full, they can claim against the accounts receivable. If the creditor is secured (by the factory or by the accounts receivable), it cannot assuredly liquidate the collateral immediately upon the bankruptcy filing, due to the Bankruptcy Code's automatic stay. And while the secured creditor must be adequately protected, that adequate protection (a) is not a guarantee of payment, but a judicial "best-efforts" obligation and (b) often does not require interest to be paid for the delay in repayment, due the interaction between Section 502(b) and Section 506, as interpreted in United Savings Association of Texas v. Timbers of Inwood Forest Associates. However, by financing the SPV, one creditor-here, the Bank-can exclude the others from claiming on the accounts receivable and,

${ }^{93}$ See id. §§ 502, 506; United Sav. Ass’n of Texas v. Timbers of Inwood Forest Assocs., 484 U.S. 365, 382 (1988).

${ }^{94}$ See supra notes 66-68 and accompanying text. 
because it can liquidate the SPV immediately upon the bankruptcy filing of the Originator, the Bank can escape the likely cost of a bankruptcy in which it would often not receive the time value of money for the delay. Arrow (1) illustrates the sale of the accounts receivable to the SPV for the cash illustrated in arrow (3). Because the Bank's relationship moves from one with the Originator (via the top solid arrow) to a relation with the SPV, via dashed arrows (2) and (4), the Bank no longer is tied up in the Originator's bankruptcy.

Structured finance enables the pre-bankruptcy lender and debtor to contract out of these potential future repayment annoyances and entanglements. The parties set up an SPV, a separate corporation that serves as the lender's formal borrower. The SPV continually buys the accounts receivable from the debtor using advances from the priority-seeking lender. With this structure, the lender divorces its credit risk from the risks of the debtor's operations, since its borrower is not the debtor but the SPV, which has no operations, but only owns the debtor's accounts receivable. If the operating debtor were ever to file for bankruptcy, the SPV would not also go bankrupt, so the lender to the SPV would not be subject to the automatic stay. This SPV lender could immediately seize its receivables collateral pursuant to its contract, sell the collateral, and lend the proceeds to another company. The lender would also not need to worry about being trumped by new DIP loans or roll-ups, since again, its borrower, the SPV, would not be in bankruptcy. For its part, the debtor uses the SPV to fund its operations by continually cashing out its receivables, at prices reflecting the lowered risk to the lender. These SPV-type transactions have mushroomed in recent decades.

\section{Lobbying for Priority: Rent-Seeking in Congress in the Lead-Up to the Financial Crisis}

Thus far we have examined transactional and litigation-based priority jumps. But for serious rent-seeking, the place to go is Congress. Bankruptcy rent-seeking in Congress was in play recently, interacting with the 2008-2009 financial crisis, in which two financial instrumentsrepos and derivatives-played central roles. ${ }^{95}$ Priority jumping is central to repos and derivatives.

Markets for the two instruments grew massively in the preceding two decades, ${ }^{96}$ and expert analysts tell us that without congressionally-

\footnotetext{
${ }^{95}$ See Roe, supra note 12 , at 549-55.

${ }^{96}$ Repo market information can be found in Fed. Reserve Bd., Statistical Supplement to the Federal Reserve Bulletin (Dec. 2008), available at http://www.federalreserve.gov/pubs/
} 
granted priority jumps, these markets would not have been viable. ${ }^{97}$ While neither instrument fundamentally caused the crisis-disruptions in the mortgage market were more basic - each priority structure arguably exacerbated financial problems during the crisis, worsening the financial failures at AIG, Bear Stearns, and Lehman Brothers. ${ }^{98}$ With a bankruptcy commission currently planning to redraft the Bankruptcy Code for Congress, ${ }^{99}$ one should expect additional important legislative bankruptcy rent-seeking in the near future.

\section{The Repo Recharacterization Jump}

Repos are agreements between a lender and borrower to sell and quickly thereafter repurchase collateral. The borrower owns an asset, but needs cash. The lender has cash but wants complete security for the lowinterest loan it is willing to make. So the borrower "sells" the asset to the lender, agreeing to repurchase (repo, for short) the asset at a fixed time, often the next day. The repurchase price is slightly higher than the sale price, with the difference serving as the interest payment. The transaction accomplishes what a secured loan does: the asset sold and repurchased is the security and the pricing differential is the interest payment. ${ }^{100}$ The lenders and borrowers want the transaction treated as a sale rather than a loan, so that the lender can jump priority and escape from several Bankruptcy Code frictions. If courts viewed the repo as a sale, the buyer-lender benefits in ways that even the secured creditor in bank-

supplement/default.htm [hereinafter Statistical Supplement], and U.S. Government Securities Dealers-Positions and Financing, Fed. Reserve Archival Sys. for Econ. Res. http://fraser.stlouisfed.org/publications/frb/page/31488 (last visited) [hereinafter Securities Dealers]. Derivatives market information can be found in ISDA Market Survey, Int'l Swaps \& Derivatives Ass'n (2010), available at http://www.isda.org/statistics/pdf/isda-marketsurvey-annual-data.pdf [hereinafter ISDA Market Survey].

${ }^{97}$ See Gorton \& Metrick, supra note 13, at 277-79.

${ }^{98}$ See Roe, supra note 12, at 555-69; see also William D. Cohan, House of Cards: A Tale of Hubris and Wretched Excess on Wall Street 138 (2009); Henry M. Paulson, Jr., On the Brink: Inside the Race to Stop the Collapse of the Global Financial System 94-100 (2010); Richard Squire, Shareholder Opportunism in a World of Risky Debt, 123 Harv. L. Rev. 1151, 1201 (2010).

${ }^{99}$ See supra note 15 and accompanying text.

${ }^{100}$ Jeanne L. Schroeder, A Repo Opera: How Criimi Mae Got Repos Backwards, 76 Am. Bankr. L.J. 565, 572 (2002). 
ruptcy does not. The buyer-lender owns the asset and the bankrupt cannot reclaim it. ${ }^{101}$

An ordinary secured creditor is barred from selling its security immediately after the debtor files for bankruptcy. ${ }^{102}$ Such a secured creditor is entitled to be adequately protected, ${ }^{103}$ but if the protection proves to be inadequate, the creditor's remedies are incomplete. ${ }^{104}$ The secured creditor also risks having its priority jumped by newly prioritized DIP lenders, a scenario we have already examined. ${ }^{105}$ Even if the secured creditor wins out eventually over the DIP lender, it must monitor the situation to better assure its eventual victory. Moreover, while waiting for the collateral, the secured creditor wants to be paid interest. Sometimes it is paid, sometimes not. ${ }^{106}$ When paid, the secured creditor is not always happy with the interest rate the court awards. ${ }^{107}$

The repo market got off to a shaky start in the 1980s. Although the lender and borrower called their transaction a sale with an obligation to repurchase, early courts did not. ${ }^{108}$ They saw the transaction for what it was, a basic secured financing transaction, which would subject the lender to the Bankruptcy Code's restrictions on secured lenders and the state-based Article 9 requirements. ${ }^{109}$ Lenders in the repo market were aghast, claiming that the repo market was vital to the economy and could not survive if their transactions were not viewed as sales. They went to Congress for relief. Congress gave it to them initially and then broadened their insulation from bankruptcy during the next two decades.

Most importantly, the repo (and derivatives) industry sought, and Congress granted, exemption from the Code's automatic stay, which would have otherwise prevented repo buyer-lenders from seizing their

\footnotetext{
${ }^{101}$ See Lombard-Wall Inc. v. Bankers Trust Co. (In re Lombard-Wall Inc.), 23 B.R. 165, 165-66 (Bankr. S.D.N.Y. 1982) (questioning whether a repo was really better characterized as a secured loan and not as a sale).

${ }^{102}$ See 11 U.S.C. § 362(a) (2006). If the creditor already possesses the security, it could be required to return it to the bankrupt, if the bankrupt needs it to operate better. See id. $\S 542(a)$.

${ }^{103}$ See id. §§ 362(d)(1), 363(e).

${ }^{104}$ See id. § 507(b).

105 See supra Subsection II.B.1.

${ }^{106}$ See 11 U.S.C. § 506 (2006).

${ }^{107}$ See Till v. SCS Credit Corp., 541 U.S. 465, 471 (2004).

${ }^{108}$ See Lombard-Wall Inc. v. Bankers Trust Co. (In re Lombard-Wall Inc.), 23 B.R. 165, 166 (Bankr. S.D.N.Y. 1982).

${ }^{109}$ See U.C.C. § 9-109(a)(1) (maintaining that transactions in the nature of security are secured transactions, "regardless of . . . form").
} 
collateral and collecting on their loans once a bankruptcy proceeding had begun. And they sought and obtained from Congress safe harbors from the application of fraudulent conveyance law and preference law, which reclaims eve-of-bankruptcy repayments to individual creditors for all creditors to share. ${ }^{110}$

This effective recharacterization of the repo lender as property owner instead of lender immunizes it from the incivilities that mainstream secured creditors suffer. Exemption from the automatic stay also insulates the repo buyer-lender from potential no-interest rules and from the risks of being jumped over by new DIP lending. ${ }^{111}$ The repo creditor does not have to worry about obtaining possession or being ousted of possession if it already has possession, because it owns the asset. Nor does it need to worry about the potential inadequacy of judicially granted adequate protection of the creditor's secured interest while it awaits the asset's return. The repo lender need not worry about a court-determined interest rate while waiting to be repaid, because it can sell its own asset and reinvest at market rates. The differences in protection and risk between a sale and secured credit status may be small in the abstract, but in the multi-trillion-dollar repo business, ${ }^{112}$ a small reduction in risk can shave a few basis points off of loans that are made in quantity repeatedly.

This recharacterization of the repo buyer/lender as a property buyer and not as a secured lender exemplifies basic priority jumping. When courts did not sanction the jump for an influential sector of the finance industry, the industry looked to Congress.

\section{The Derivatives Market's Priority Jump}

Derivatives are side bets on fundamental financial events. The archetypical derivative is for foreign exchange: A company exposed to the ups and downs of the euro-dollar exchange rate transfers this risk to another firm by agreeing that it will pay up if the euro moves in one direction but will receive payments if the euro goes in the other direction. To

\footnotetext{
${ }^{110}$ On repo players' authority to liquidate collateral in their possession, see 11 U.S.C. $\S \S 362$ (b)(17), 362(b)(27), 560 (2006); on exemptions from preference rules, see id. $\S 546(\mathrm{~g})$, (j); on setoff breadth, see id. $\S \S 553(\mathrm{a}), 560$; on exemption from constructive fraudulent conveyance liability, see id. § 546(g), (j); and on ability to terminate repos, swaps, and master netting agreements, see id. §§ 555, 559-61.

111 See id. § 541.

${ }^{112}$ See Statistical Supplement, supra note 96; Securities Dealers, supra note 96 (repo market); ISDA Market Survey, supra note 96 (derivatives market).
} 
assure payment, the parties can give one another security for their obligations. If one of them fails, the other would normally enjoy the status of a secured creditor, which is treated well in bankruptcy but as earlier noted, faces frictions. Derivatives players would like to avoid these frictions and jump priority over other creditors. In bankruptcy conceptualization, there is no reason to allow this. ${ }^{113}$ Hence, the derivatives players wanted congressional relief, which they obtained in the decades leading up to the financial crisis. ${ }^{114}$

Before this congressional relief arrived, derivatives counterparties faced bankruptcy risks similar to the repo players. If a party to a derivatives contract failed and filed for bankruptcy, the counterparty typically wanted to terminate the contract immediately and seize and sell the underlying security if the counterparty was in the money. It did not want to wait for the contract to be resolved (often without interest being paid). But bankruptcy law imposed all of these difficulties on the counterparty and more. Basic bankruptcy law allows the bankrupt to "play the market”: It may hold open contracts in abeyance and decide as the bankruptcy proceeds whether to affirm or reject each contract. ${ }^{115}$ Under normal bankruptcy doctrine, the bankrupt could wait a significant period before deciding. ${ }^{116}$ If the market had moved in its favor, it would affirm the contract. If the market had moved against it, it would reject the contract. All those who deal with potential bankrupts face such risks, but openended, volatile financial contracts such as derivatives contracts created greater risks for the bankrupt's counterparties than the norm. ${ }^{117}$

Armed with arguments and lobbying muscle, the derivatives industry went to Congress repeatedly over the last few decades to obtain exceptions from ordinary bankruptcy practice. In 1982, Congress excepted certain derivatives contracts and counterparties from the automatic stay, enabling counterparties to close out these contracts as soon as the debtor

\footnotetext{
${ }^{113}$ See Roe, supra note 12 , at 581.

${ }^{114}$ Id. at 576 ("[Financial] players lobbied hard to get derivatives priorities extended in 1982, 1984, 1994, 2005, and 2006, and to keep them in 2010.”).

${ }^{115}$ See 11 U.S.C. § 365 (2006).

${ }^{116}$ See id. $\S 365(d)(2)$ ("In a case under chapter 9, 11, 12, or 13 of this title, the trustee may assume or reject an executory contract or unexpired lease of residential real property or of personal property of the debtor at any time before the confirmation of a plan ....”).

${ }^{117}$ Stephen J. Lubben, The Bankruptcy Code Without Safe Harbors, 84 Am. Bankr. L.J. 123, 135 (2010) (arguing that the Bankruptcy Code is ill-equipped to handle "the possibility of a claim that might change in value on a daily or hourly basis”).
} 
went bankrupt. ${ }^{118}$ In 1990, Congress extended the Code's protection of derivatives contracts, excepting them from preference rules and limiting debtors' ability to accept or reject the contracts under Section $365 .{ }^{119}$ These rules have since been expanded to further improve derivatives participants' status in the bankruptcy process. ${ }^{120}$

As Congress progressively improved the bankruptcy treatment of derivatives counterparties in recent decades, the derivatives market ballooned, extending beyond the archetypical foreign exchange derivative described above to include credit default swaps (that is, obligations derived from a firm's debt), which function as guarantees (and were central in the AIG failure), as well as exotica like derivatives based on weather or price movements of a single natural resource. ${ }^{121}$ In failures such as AIG, the derivatives counterparties with good collateral transferred risk and illiquidity onto the debtor's other creditors. ${ }^{122}$ This was priority jumping.

Overall, these priority jumps-from critical vendor to structured finance via SPVs to roll-ups to repos and derivatives-are substantial. The underlying transaction types either arose for the first time or grew massively in recent decades. A researcher would be hard pressed to find many major bankruptcies of the past decade or so where one or another or several of these priority jumps did not play a central role. Modern priority jumping is thus at the core of the action in Chapter 11, at least as much as is the resolution of pre-set "absolute" priorities. Perhaps a Chapter 11 process that had the predictable creditors' bargain as its central feature would be superior to what we have-and we have much sympathy with that view-but it is just not how on-the-ground Chapter 11 has worked for several decades.

\footnotetext{
${ }^{118}$ See Act of July 27, 1982, Pub. L. No. 97-222, § 3(c), 96 Stat. 235, 236 (codified as amended at 11 U.S.C. § 362(b)(6) (1982)); see also Bankruptcy Amendments and Federal Judgeship Act of 1984, Pub. L. No. 98-353, § 392, 98 Stat. 333, 365 (codified as amended at 11 U.S.C. § 362(b)(7) (1984)); Act of June 25, 1990, Pub. L. No. 101-311, § 102(3), 104 Stat. 267, 267 (codified at 11 U.S.C. § 362(b)(17) (1990)).

${ }^{119}$ See Act of June 25, 1990, Pub. L. No. 101-311, §§ 103, 106, 104 Stat. 267, 268 (codified at 11 U.S.C. §§ 546(g), 560 (1990)).

${ }^{120}$ See Bankruptcy Reform Act of 1994, Pub. L. No. 103-394, § 501(d)(7)(B)(vii), 108 Stat. 4106, 4144 (codified as amended at 11 U.S.C. § 362(b) (1994)); Bankruptcy Abuse Prevention and Consumer Protection Act of 2005, Pub. L. 109-8, § 907(a)(1)(E), 119 Stat. 23, 172-73 (codified as amended at 11 U.S.C. § 101 (2005)).

${ }^{121}$ See generally Jongho Kim, From Vanilla Swaps to Exotic Credit Derivatives: How to Approach the Interpretation of Credit Events, 13 Fordham J. Corp. \& Fin. L. 705 (2008).

${ }^{122}$ Roe, supra note $12,550-51$.
} 
The Appendix details other recent priority jumps: gift plans, exemptions from fraudulent conveyance liability, and erosion of securities law subordinations via the Sarbanes-Oxley Act. And historically there have been yet more jumps, including the equity receivership, the Chapter $\mathrm{X}$ valuation process, and the marshaling doctrine, each of which we also briefly examine in the Appendix. Together these examples further evidence the regularity of priority jumping and its place as a routine feature of corporate reorganization.

\section{IMPLICATIONS}

What are the policy and theoretical ramifications of considering priority as a process? The first issue is how we conceive of bankruptcy: bankruptcy's priority structure is never "done.” It should not be viewed as a static creditors' bargain, where creditors find their place in a fixed architecture of priorities and then charge for their expected risk. In an important, now-classic analysis, Thomas Jackson showed how bankruptcy should be analyzed normatively for its conformity to a contractarian creditors' bargain: What structure would creditors collectively desire to process their claims? And, the argument ran, key elements of bankruptcy law should be seen as conforming to the creditors' bargain model. Deviations should then be suppressed. ${ }^{123}$ While we share several of the normative perspectives embedded in the creditors' bargain view, our point here is that the bankruptcy priority structure is regularly mutating, with rent-seeking driving much of the mutation. The framework is never finished; it is always contested.

From this condition of persistent mutation emerges the second major conceptual issue-efficiency. True, there is good reason to think that some priority adjustments follow and facilitate financial innovation, thereby improving the bankruptcy process and lending practices outside of bankruptcy. ${ }^{124}$ Overall, the Section 363 sale, in our view, plays that role. But there is also reason to think that bankruptcy rent-seeking gen-

\footnotetext{
${ }^{123}$ See Jackson, Logic and Limits, supra note 16, at 24-27; Jackson, Creditor's Bargain, supra note 16, at $860,907$.

${ }^{124}$ See Douglas G. Baird \& Robert K. Rasmussen, Boyd's Legacy and Blackstone’s Ghost, 1999 Sup. Ct. Rev. 393, 412-425 (demonstrating that priority rules in bankruptcy have been modified over the years to reflect economic and financial market trends); Omer Tene, Revisiting the Creditors' Bargain: The Entitlement to the Going-Concern Surplus in Corporate Bankruptcy Reorganizations, 19 Bankr. Dev. J. 287, 387 (2003) (“[Bankruptcy] law follows the market....”).
} 
erates more than the optimal level of adjustment and that it draws resources away from activities more socially useful than a priority arms race.

Some inefficiencies are local and transactional: financial markets may be damaged or firms made less effective, but with no systemic implications. Other times, inefficiencies can be deep and wide if major markets experience priority jumps and the process of reacting to the change is widespread but sticky. If markets and creditors react slowly and adjustment takes years, then rent-seeking could induce substantial inefficiencies. There is reason to think that the priority jumps in the derivatives and repo markets in recent decades caused systemic debilities, thereby contributing to the severity of the 2007-2009 financial crisis. ${ }^{125}$

This Part explores these important consequences of priority jumping.

\section{A. Dynamic Creditor Bargains}

We can understand why rent-seeking has not been integral to the scholarly conceptualization of bankruptcy. According to convention, bankruptcy priorities are conceptually clear-priority is "absolute"-and priority is typically implemented in courts, not by administrative agencies responsible to Congress. Courts are the least likely venue for successful rent-seeking in the American legal system, and most restructuring deals in isolation do not immediately implicate major rent-seeking.

If instead, bankruptcy priority is mutating regularly, then the process is more dynamic. Here is how we would recharacterize the bankruptcy process. Creditors begin by bargaining inside a priority framework. Existing rules reflect and implement that bargain, for the most part. But creditors can contest the rules and obtain favorable rule changes. If change were infrequent, we could simply think of the creditors' bargain as being reset. It would then proceed under the new rules. Years later, it might be reset again. But in fact, creditors regularly contest the rules through innovative transactions, litigation, and legislation, such that the creditors' bargain is always in flux. Every priority jump induces attempts by creditors to retrade their existing bargains and to replan their prospective ones. In our view, highlighting this dynamic contestation of rules is necessary to describe the reality of bankruptcy.

Moreover, this reconceptualization implicates related, standard bankruptcy concepts. Though we traditionally think of bankruptcy as merely

${ }^{125}$ Roe, supra note 12 , at $549-54$. 
a process of ordering state-based claims, ${ }^{126}$ priority jumping analysis tells us that it is more than that. State-law-oriented conceptualizations are incomplete. Under state law, trade creditors, who enjoy equal priority in payment, would be paid based on who wins the race to the courthouse. The traditional creditors' bargain in bankruptcy collectivizes their collection efforts while recognizing their equal priority status under state law. Under that approach, they all would wait to receive equal treatment. But under modern bankruptcy, a critical vendor doctrine jumps some to the head of the vendor payment line, not by reintroducing a race to the courthouse but by introducing a doctrine that jumps priority for those whom the bankruptcy process deems critical.

Similarly, the repo and derivatives rules can be contrasted with both state law and the Bankruptcy Code's creditors' bargain. Under state law, creditors can liquidate their security and apply it to their loan; for the most part secured creditors cannot do so in bankruptcy, as the automatic stay prevents the liquidation. But for derivatives and repo creditors, the Code makes an exception, allowing them their state remedies. In place of a race to the courthouse, the Code establishes a race for repo or derivatives status, which accords the winners immediate access to special remedies that the Code denies other creditors.

\section{B. Is Priority Jumping Efficient?}

We make the positive, conceptual case that bankruptcy is not the static, contractarian institution that has come to dominate much of bankruptcy thinking. It is rife with rent-seeking, the costs of which tax the efficiency of the bankruptcy process. With the rent-seeking, prioritybreaking concepts we propose in mind, bankruptcy scholars can better analyze bankruptcy's efficiencies and inefficiencies going forward. We outline the core efficiency considerations in this Section.

The efficiency properties of priority jumping are intimately related to its political economy. We can evaluate the efficiency of priority jumping with the standard framework used to analyze the efficiency effects of legal change, with both ex post and ex ante costs and benefits relevant.

\footnotetext{
${ }^{126}$ Douglas G. Baird, Loss Distribution, Forum Shopping, and Bankruptcy: A Reply to Warren, 54 U. Chi. L. Rev. 815, 816-22 (1987); Douglas G. Baird \& Thomas H. Jackson, Corporate Reorganizations and the Treatment of Diverse Ownership Interests: A Comment on Adequate Protection of Secured Creditors in Bankruptcy, 51 U. Chi. L. Rev. 97, 109-11 (1984).
} 
The major ex post costs and benefits of any given priority jump depend on whether and how jumped creditors adjust to a new priority rule, and whether post-jump adjustments enhance or diminish firm value. The major ex ante costs are rent-seeking costs-the influence costs discussed above, ${ }^{127}$ as well as the costs of uncertainty. Contestable priority rules make creditors' returns more variable and harder to predict. The greater variance of their returns may cause creditors to raise their prices or forgo what would otherwise be value-increasing transactions.

It is difficult to generalize about ex post effects of a priority jump on firm value. However, the rent-seeking costs of priority jumpinginfluence costs and uncertainty costs-strongly suggest that priority jumping may overall be inefficient, with only few jumps providing unambiguous efficiency improvements.

\section{Ex Post Costs: Adjusting to Priority Jumps}

Once a creditor jumps priority, if the jump occurs against competing creditors' expectations, then the winners receive an immediate windfall in the transaction at hand unless the losers are able to adjust the terms of their credit immediately and at a low cost. More generally, if the jump is likely to repeat in future transactions, the losers would need to adjust all of their other existing and potential transactions, either by raising the price of their credit or reducing the amount of their lending in the affected markets. ${ }^{128}$

According to Modigliani and Miller's famous irrelevance propositions, priority jumps would not have lasting inefficiencies in a frictionless world. ${ }^{129}$ In a frictionless world, a firm cannot increase its value by taking on an optimal level of risky debt, because the risk assumed by taking on risky debt is simply drained away from the firm's other investors. Those other investors, upon learning that they are advantaged by the other debt that is sopping up more risk, should be willing to lower their demanded return because their advantaged debt would have been

\footnotetext{
${ }^{127}$ See supra Section II.A.

${ }^{128}$ Or they could counterattack in the legal system, a subject discussed earlier. See supra Subsection II.B.1.

${ }^{129}$ Under assumptions of market regularities-perfect information, no tax distortions, and no bankruptcy or recapitalization costs-Modigliani and Miller demonstrated, in one of finance's most compelling theorems, that financial structure does not matter to firm value. Franco Modigliani \& Merton H. Miller, The Cost of Capital, Corporation Finance and the Theory of Investment, 48 Am. Econ. Rev. 261, 296 (1958).
} 
made less risky. In smoothly functioning markets, the adjustment is immediate and what the firm gains when dealing with one investor, it must lose to another investor.

Creditors and firms of course do care deeply about priority, and a good deal of theoretical financial analysis focuses on identifying where the exceptions to the Modigliani-Miller Hypothesis arise. ${ }^{130}$ With priority jumping, the more quickly the losers can adjust at low cost, the closer it is to being a wash in terms of overall firm value. More risk and return for one creditor, then, simply means less risk and return for another. ${ }^{131}$ Firm value would change little. But if the losers cannot react well and quickly in the market, then there will be a continuing transfer from losers to winners beyond the transaction at hand. At the least, the losers may have other similar existing but now disfavored investments that do not mature for a time and cannot be adjusted quickly and at low cost. Or they may suffer institutional constraints that preclude them from reacting immediately.

If jumped creditors cannot adjust, the jump could be ex post inefficient. Focusing on only the value of the various creditors' post-jump claims on the firm, the loss to losers would outweigh the gains to winners in a given transaction. Moreover, losers' inability to adjust would encourage winners to excessively use the newly favored financing in order to transfer value to themselves from the losing creditors, even if overall firm value were reduced. One could imagine, for example, a firm incurring more short-term, overnight repo financing than is ideal after it becomes clear that this financing form will receive more favorable treatment in bankruptcy than other loans. ${ }^{132}$ Because creditors will price overnight repo financing attractively, reflecting its favored status in bankruptcy, the debtor firm will naturally be drawn to this financing form, even if its overuse might diminish firm value overall. And there are large classes of creditors who without a doubt cannot adjust. ${ }^{133}$ Simi-

\footnotetext{
${ }^{130}$ Richard Brealey et al., Principles of Corporate Finance 440-501 (10th ed. 2011).

${ }^{131}$ Cf. Lucian Arye Bebchuk \& Jesse M. Fried, The Uneasy Case for the Priority of Secured Claims in Bankruptcy, 105 Yale L.J. 857, 864 (1996) (noting categories of creditors who may be unable to adjust to changes in priority rankings).

${ }^{132}$ Certainly the volume of repo financing skyrocketed after major events clarifying the favorable bankruptcy treatment for that financing. See Gorton \& Metrick, supra note 13, at 278.

133 Tort creditors and the government as a tax or regulatory creditor typically cannot adjust future transactions to account for the latest priority jump, let alone adjust existing transactions. Small claimants typically do not and cannot adjust existing transactions. See Bebchuk
} 
larly, SPVs could be priced attractively to the debtor, be costly to some of the debtor's other creditors, and then be overused.

Besides its subordinating effect, a priority jump may transfer risk in other ways. Consider the likelihood that some creditors and equity holders rely on the signal emanating from bank lending and monitoring. ${ }^{134}$ Banks then obtain a jump in priority through, say, easier roll-up of weak pre-bankruptcy loan positions into super-prioritized DIP loans. The banks' newfound opportunity-to-jump induces them to slack off on their monitoring, and their signals of debtor quality become less valuable. Even if other parties who had relied on bank signals are aware of the change, their institutional structures and lending and investing practices may depend on the continuing high quality of these signals. Other parties incur adjustment costs following the banks' priority jump. Priority jumping thus has ripple effects in addition to subordinating losing creditors.

These observations are not to say that all jump-induced changes in financing arrangements reduce firm value. Changes in priority rules and other financial regulation sometimes facilitate new, more efficient modes of financing. Without information about the adjustments to firms' financing and investments induced by priority jumping, it is difficult to generalize about whether priority jumps are transactionally efficient.

\section{Ex Ante Influence Costs and the Costs of Uncertainty}

The availability of priority jumps naturally attracts resources in their pursuit. Influence and uncertainty costs rise. These rent-seeking costs are

\& Fried, supra note 131, at 882-91. Subordination agreements or some type of covenant protection could enable voluntary creditors to adjust existing transactions to account for priority jumps. Small claimants, however, are unlikely to enjoy the negotiating leverage or the advice of counsel to obtain these ex ante protections from their borrowers. If they fail to adjust their future transactions, either by pricing the increased risk or reducing their lending in risky markets, they go out of business.

${ }^{134}$ See James R. Booth, Contract Costs, Bank Loans, and the Cross-Monitoring Hypothesis, 31 J. Fin. Econ. 25, 25-26 (1992); Sudip Datta et al., Bank Monitoring and the Pricing of Corporate Public Debt, 51 J. Fin. Econ. 435, 448-49 (1999); Joanna M. Shepherd et al., What Else Matters for Corporate Governance?: The Case of Bank Monitoring, 88 B.U. L. Rev. 991, 992-1006 (2008); George G. Triantis \& Ronald J. Daniels, The Role of Debt in Interactive Corporate Governance, 83 Calif. L. Rev. 1073, 1078 (1995); Frederick Tung, Leverage in the Board Room: The Unsung Influence of Private Lenders in Corporate Governance, 57 UCLA L. Rev. 115, 125-29 (2009); Steven Ongena et al., Banks and Bonds: The Impact of Bank Loan Announcements on Bond and Equity Prices 3 (Nov. 2008), available at http://www.tilburguniversity.edu/webwijs/files/center/ongena/preprints/orw.pdf. 
in play across the board, sometimes outweighed by transactional efficiency, sometimes not. In general, the most sophisticated, best-organized, and best-financed creditor groups are best positioned to pursue and obtain priority jumps than other types of creditors. These creditor types are also likely to be the creditors best able to adjust to new priority jumps that might otherwise disfavor them. Priority jumping in this dimension can therefore simply be an arms race among sophisticated creditors, a race that serves to achieve only short-term advantages, which get competed away. Over the long haul in this scenario, none of the sophisticated creditors are better off.

The competitive priority jumping among unsecured financial creditors, DIP lenders, and SPV lenders discussed earlier may exemplify this dynamic: Each type of creditor can invest resources in pursuit of a priority jump or adjust over time to being jumped, either through its pricing of risk, transactional innovation, litigation, or lobbying. The same may be said about repo priority, which resulted in expanded reliance on repo financing that substituted for commercial paper financing. ${ }^{135}$ The same money market investors often lend in both forms. ${ }^{136}$ And less sophisticated unsecured creditors with difficulty adjusting will be subordinated in any event in these markets, so they may be no better or worse off. Ex post efficiency effects are unlikely to be positive in this scenario; rentseeking and reactive adjustment costs are likely to dominate, suggesting that priority jumping here is on the whole inefficient.

Moreover, a contested priority jump is typically not resolved cleanly or quickly. It is often contested in multiple forums before clarity develops on the legal status of the attempted priority jump. For example, recall the DIP lenders' pursuit of cross-collateralization and roll-up priority, discussed earlier, which involved multiple litigated cases across multiple judicial circuits. ${ }^{137}$

Features peculiar to bankruptcy litigation may exacerbate rentseeking costs in these scenarios. Because of the dearth of bankruptcy appeals, ${ }^{138}$ bankruptcy judges enjoy autonomy in administering their

\footnotetext{
${ }^{135}$ See Roe, supra note 12 , at $557-58$.

${ }^{136} \mathrm{Id}$. at 557. The more difficult issue for repo priority is when the risk transferred ends up being picked up by the U.S. Treasury, as it effectively is when it moves to the bank deposit base or when it otherwise involves serious systemic risks. But that is not the topic of this Article.

${ }^{137}$ See supra Subsection II.B.1.

${ }^{138}$ See supra note 49 and accompanying text.
} 
cases. Some courts may compete to attract large cases to their courts. ${ }^{139}$ To that end, they may offer decisions attractive to "case placers"140 - the lawyers and their clients who influence where large reorganizations get filed. The pattern of large case filings shows that only a handful of the hundreds of bankruptcy courts in the United States are serious competitors. But the courts that do compete may sometimes allow practices that are not clearly authorized in the Bankruptcy Code-roll-ups or extensive critical vendor payments, for example. ${ }^{141}$

One can imagine that as part of the pre-bankruptcy negotiation between a debtor and its dominant bank lender, if DIP lending were contemplated, the lender might insist that the bankruptcy filing be made in a jurisdiction sympathetic to roll-up priority. As long as the debtor and lender are amenable to the roll-up, why chance the possibility that their agreed-to financing arrangement might be disapproved by the judge? Hence, there could be even more priority jumping than reported cases would indicate: a jurisdiction amenable to roll-ups may attract more filings involving roll-ups and more settlements based on roll-ups because of the key players' desire that the old debt be rolled into the DIP loan.

The autonomy of bankruptcy judges and the enthusiasm of some courts to compete for large cases may attract investment in competitive rent-seeking. These bankruptcy litigation dynamics may impede the prompt resolution of legal uncertainty, a circumstance perversely well suited to attracting costly investments in priority jumping. To the extent that creditor groups believe that priority jumps may be attainable through transactional innovation and litigation, they may be tempted to invest resources pursuing favorable legal changes. And the lawyers that pioneer an ultimately successful priority jumping technology will attract business from debtors and creditors that wish to make use of the technology. So lawyers have repeat-play incentives to experiment with the

\footnotetext{
${ }^{139}$ Landing a case typically brings a wealth of fees to local bankruptcy professionals-not only lawyers, but accountants, bankers, consultants, and the like. Because bankruptcy judges are typically chosen from the local bankruptcy bar, they can be loyal to their former colleagues in private practice. Presiding over a large case may also be exciting for a bankruptcy judge. Federal appellate and district court judges are typically not similarly attached to local bankruptcy practice, so bankruptcy courts are the primary locus of this competition for cases.

${ }^{140}$ LoPucki, supra note 83, at 137-40.

${ }^{141}$ Kmart illustrates one potential effect of federal appellate court intervention into this case competition among bankruptcy courts. Following Kmart, large Chapter 11 cases reportedly stopped coming to Chicago. See Douglas G. Baird, Bankruptcy from Olympus, 77 U. Chi. L. Rev. 959, 959-61 (2010). Major decisions thwarting debtors' druthers may cause debtor lawyers to shop for more friendly venues.
} 
technology and advertise their expertise, ${ }^{142}$ which may attract still more resources to the pursuit of and defense against priority jumps.

This process may also generate non-uniformity of priority rules across jurisdictions, with the legal status of attempted priority jumps varying across courts, districts, and circuits for years. As priority-jumping activities increase, uncertainty and its attendant costs rise, especially for those creditors who cannot seamlessly adjust to new priority rules and the higher risk they bear. Continually changing priority rules should dampen otherwise worthwhile financing transactions because creditors are unable to clearly anticipate or respond to unexpected risk transfers.

Even if the potential financier believes it is as likely to obtain a priority jump as it is to be on the losing end, the increase in variance, if not fully diversifiable, deters some financing. The transaction costs of defense (or offense) could also lead creditors to prefer transactions with firms with lower chances of being affected by priority jumping, even if those firms might otherwise be less creditworthy. Moreover, some classes of creditors are less likely to obtain priority jumps. They will need to charge more as a risk premium, and/or will avoid some financing transactions.

We do not attempt a hard and fast conclusion that priority jumping is inherently bad (or good), and we doubt that such an assured conclusion is obtainable. But we do show that jumping involves a mix of rentseeking, improved rules, and re-contracting among the bankruptcy players. The last two features are not new to business bankruptcy thinking; the first is, however. Before we can come to grips with the costs and benefits of rent-seeking or query how we might guide rent-seeking into its most productive channels, we must update the conventional creditors' bargain view by incorporating the priority jumping phenomenon into our bankruptcy thinking.

From a political economy perspective, bankruptcy is no different from banking regulation, securities law, or other areas of financial regulation, where the continuing interaction among regulators, courts, and the regulated has long been the subject of academic and policy study. Priority jumping has the same pathologies that plague these other areas of financial regulation. The creditors' bargain construct reveals one dimension

\footnotetext{
${ }^{142}$ At a certain point, of course, if and when the law becomes settled, the technology becomes easily replicated.
} 
of the bankruptcy process; our rent-seeking, priority-jumping perspective reveals a second, equally important dimension.

\section{CONCLUSION}

We have reconceptualized bankruptcy as a process in which creditors repeatedly break priority so as to favor themselves. They invent new transactions, pursue new court doctrines, and lobby legislatures for new rules that yield them higher priority. They defend against priority jumping by structuring stronger transactional positions, by opposing newly offered doctrines in court or by offering alternatives, and by seeking legislative reversal of judicially created priorities.

Bankruptcy thus needs to be reframed as a dynamic rent-seeking process as much as one of creditors hypothetically bargaining within a static framework of absolute priority, because the priority framework is fluid and contested. The creditors' bargain may be normatively superior to rent-seeking, but it is an incomplete description that overlooks the rentseeking process we have described. Sometimes the resulting transactional, doctrinal, and legislative structures are more efficient and fair than what they replace. But with priority so often up for grabs, considerable investment in the distributional rules cannot be perfectly efficient, and will be afflicted with pathologies.

Faced with priorities they dislike, financiers and their lawyers innovate with new transactions. That is often the cheapest way to break priority, as compared with lobbying a reluctant Congress. If challenged, they defend their newly acquired priority in litigation. If they lose, or if they need confirmation, they consider whether to seek legislation to overturn courts and old rules. This is core to the process of bankruptcyin-action.

\section{APPENDIX. AdDITIONAL CONTEMPORARY AND HISTORICAL PRIORITY JUMPS}

This Appendix recounts three additional recent priority jumps, as well as three historical priority jumps under reorganization regimes that preceded the current Chapter 11 of the Bankruptcy Code.

One might think that priority jumping is a modern phenomenon, induced by the accelerating financial complexity of American business. But this is not so. Priority jumping characterized corporate reorganiza- 
tion in the past, going back to its origins in the nineteenth century. It has been a continuing feature of the reorganizing of bankrupt businesses.

In addition, although we do not detail them here, priority jumps can be found in the bankruptcy rules covering pension and health benefits, labor union contracts and their rejection in Chapter 11, and interest payment and nonpayment. ${ }^{143}$

\section{A. Recent Priority Jumps}

Besides the priority jumping activity recounted in the main text, recent priority jumping activity has involved gift plans, safe-harbored payments to shareholders in leveraged buyouts, and payments to shareholder victims of the debtor's securities fraud.

\section{Gift Plans}

Even the core of the venerable absolute priority rule has been subject to sporadic successful priority jumps, through so-called "gift" plans approved by particular bankruptcy courts. ${ }^{144}$ A gift plan circumvents the absolute priority rule by paying favored junior claimants or interests indirectly through the intercession of senior creditors. ${ }^{145}$ The plan initially

\footnotetext{
${ }^{143}$ For pension and benefits priorities, see 11 U.S.C. $§ 1114$ (2006); Pension Benefit Guar. Corp. v. Ouimet Corp., 470 F. Supp. 945, 949-54 (D. Mass. 1979), aff'd 630 F.2d 4 (1st Cir. 1980); LTV Corp. v. Pension Benefit Guar. Corp. (In re Chateaugay Corp.), 115 B.R. 760, 779-80 (Bankr. S.D.N.Y. 1990); In re DIVCO Phila. Sales Corp., 64 B.R. 232, 234-35 (Bankr. E.D. Pa. 1986); In re Cott Corp., 47 B.R. 487, 495 (Bankr. D. Conn. 1984); Dennis R. Dow \& Mark Moedritzer, ERISA-Related Claims in Bankruptcy, 3 J. Bankr. L. \& Prac. 76, 83-94 (1993); James W. Giddens, Attempting to Protect Employee Retirement Income Within Bankruptcy Reorganization: PBGC Efforts to Obtain Priority Status, 12 Ann. Rev. Banking L. 397, 397-401 (1993). For union contracts, see 11 U.S.C. § 1113 (2006); NLRB v. Bildisco \& Bildisco, 465 U.S. 513, 514-15 (1984). For interest payments and nonpayments, see Assocs. Commercial Corp. v. Rash, 520 U.S. 953, 953-54 (1997); United Savings Ass'n of Tex. v. Timbers of Inwood Forest Assocs., 484 U.S. 365, 365-66 (1988); Cont'l Ill. Nat'l Bank \& Trust Co. v. First Nat'l City Bank (In re King Res. Co.), 528 F.2d 789, 791-92 (10th Cir. 1976).

${ }^{144}$ See, e.g., In re Journal Register Corp., 407 B.R. 520, 525, 529-30 (Bankr. S.D.N.Y. 2009); In re Union Fin. Servs. Grp., 303 B.R. 390, 422-23 (Bankr. E.D. Mo. 2003); In re Parke Imperial Canton, Ltd., No. 93-61004, 1994 WL 842777, at *5-6 (Bankr. N.D. Ohio Nov. 19, 1994).

${ }^{145}$ For a discussion of the history and mechanics of a "gift plan," see Bussel \& Klee, supra note 60, at 709-13; see also Harvey R. Miller \& Ronit J. Berkovich, The Implications of the Third Circuit's Armstrong Decision on Creative Corporate Restructuring: Will Strict Construction of the Absolute Priority Rule Make Chapter 11 Consensus Less Likely?, 55 Am. U. L. Rev. 1345, 1390-412 (2006).
} 
distributes value only to claimants senior to the dissenting class, but then senior claimants redirect a part of their consideration to a class junior to the dissenters, with the plan and the parties characterizing the otherwise forbidden distribution as a "gift" from senior to junior classes. ${ }^{146}$ The doctrinal rationale for permitting this scheme is that senior claimants are free to dispose of their distributions in any way they wish. ${ }^{147}$ Especially when the senior claimant holds a secured claim whose value exceeds the combined value of the gift distribution plus the distribution retained by the senior claimant, a court might be persuaded to view the gift as a disposition of the senior claimant's property, and not estate property. ${ }^{148} \mathrm{Ei}$ ther that, or plan proponents may argue that recipients are not receiving their otherwise forbidden distributions "on account of" their junior claims or interests, but are being paid for some other reason. ${ }^{149}$

The "gift," of course, is not charitable. The gifting creditor concludes in its own self-interest that more value can be had from the firm if some lower-ranking creditors are paid more. One could think of the gift as a signing bonus-manager-stockholders are given stock to which they would not be entitled under a narrow application of absolute priority, but the senior creditor concludes that the creditor will overall get better returns if the stockholder-managers are better motivated. Similarly, the senior creditor could concede value on the bankrupt's debts due to its employees and its labor union, if it concluded that a well-motivated work force was worth the extra consideration.

The Second and Third Circuits invalidated the plans before them, ${ }^{150}$ explicitly recognizing the breadth of manipulation that gift plans might

\footnotetext{
${ }^{146}$ See In re MCorp Fin., Inc., 160 B.R. 941, 960 (S.D. Tex. 1993) (holding that the absolute priority rule is not violated when a junior claimant is "paid by the seniors out of their higher-priority share”); In re Genesis Health Ventures, Inc., 266 B.R. 591, 618 (Bankr. D. Del. 2001) (finding no violation of absolute priority when management equityholders received a distribution over the objection of creditors because the distribution "represents an allocation of the enterprise value otherwise distributable to the Senior Lenders, which the Senior Lenders have agreed to offer to the top executives").

${ }^{147}$ See Genesis Health Ventures, 266 B.R. at 618.

${ }^{148}$ See id.; see also DISH Network Corp. v. DBSD N. Am., Inc. (In re DBSD N. Am., Inc.), 634 F.3d 79, 97 (2d. Cir. 2011); In re Armstrong World Indus. Inc., 432 F.3d 507, 514 (3d. Cir. 2005) (distinguishing Genesis Health).

${ }^{149}$ See Armstrong World Indus., 432 F.3d at 515 (discussing the debtor plan proponent's argument that the debtor's parent corporation - the debtor's old equityholder-would receive new warrants to buy common stock in the reorganized debtor, not on account of its equity interest but as consideration for the settlement of intercompany claims).

${ }^{150}$ Id. at 518; see also DBSD N. Am., 634 F.3d at 108.
} 
spawn. ${ }^{151}$ Gift plans might routinely be used to circumvent the absolute priority rule by simply characterizing forbidden distributions to junior claimants as gifts from senior claimants. "Shareholders retain substantial control over the Chapter 11 process, and with that control comes significant opportunity for self-enrichment at the expense of creditors .... [A] weakened absolute priority rule could allow for serious mischief between senior creditors and existing shareholders." 152 These circuit decisions also viewed skeptically the debtors' arguments that existing equityholders-junior to all other claimants-received gift plan distributions on account of something other than their junior interests. The "continued cooperation and assistance" of existing equityholders, for example, was not a consideration independent of those equityholders' junior interests. ${ }^{153}$ So the proposed distribution violated absolute priority. ${ }^{154}$ The senior creditor could have agreed to the gift not to motivate the managerial capacities of the equityholders, but to induce them to favor and support a bankruptcy plan that benefited the senior creditors at the expense of other creditors.

\section{LBO Fraudulent Transfer Risk and the Section 546(e) Liability Insulator}

Leveraged buyout (“LBO”) lenders and stockholders face fraudulent transfer risk - the risk that, should the LBO target ultimately fail, crucial transfers in the deal might be avoided under Section 548 of the Bankruptcy Code and returned to the bankrupt estate. Because the transaction relies on the LBO target's assets to secure the financing to purchase the target company from its shareholders, the LBO requires the transfer of security interests in the target's assets to the LBO lenders and the transfer of loan proceeds to the target's shareholders as deal consideration. Courts have recognized actions to avoid both sorts of LBO transfers as

\footnotetext{
${ }^{151}$ See Armstrong World Indus., 432 F.3d at 514-15 ("Allowing this particular type of transfer would encourage parties to impermissibly sidestep the carefully crafted strictures of the Bankruptcy Code, and would undermine Congress's intention to give unsecured creditors bargaining power in this context.”); see also DBSD N. Am., 634 F.3d at 95-101.

${ }^{152}$ DBSD N. Am., 634 F.3d at 100.

${ }^{153}$ Id. at 96 (quoting In re DBSD N. Am., Inc., 419 B.R. 179, 212 n.140 (Bankr. S.D.N.Y. 2009))

${ }^{154}$ Id. at $96-97$.
} 
fraudulent. ${ }^{155}$ LBOs have been major, recurring transactions, so priority mutations for LBOs count in the dealmaking, restructuring world.

Though application of fraudulent transfer laws to LBOs is not without controversy, ${ }^{156}$ absent avoidance, the LBO transfers described above can prejudice the existing claims of the target's creditors and benefit target shareholders. Shareholders get cashed out in the LBO, while unsecured creditors are left to collect against a debtor that is much less creditworthy after the LBO than before. ${ }^{157}$ The badly constructed LBO reverses the traditional priority of creditors over equityholders by cashing out the equityholders while leaving unsecured creditors in some degree of peril.

Application of fraudulent transfer law frustrates this attempted priority jump by equityholders if the LBO rendered the target firm insolvent. However, after an initial spate of LBO fraudulent transfer decisions that favored unsecured creditor interests, ${ }^{158}$ equityholders hit upon a new argument in defense that preserves their LBO priority jumps. They argued that their LBO payments count as "settlement payments" under Bankruptcy Code Section 546(e), a provision that insulates "settlement pay-

${ }^{155}$ See, e.g., United States v. Tabor Court Realty Corp., 803 F.2d 1288, 1297 (3d Cir. 1986) (upholding the fraudulent transfer liability of the LBO lender); Wieboldt Stores v. Schottenstein, 94 B.R. 488, 504 (N.D. Ill. 1988) (refusing to dismiss the complaint as to controlling shareholders, officers, directors, and the LBO lenders).

${ }^{156}$ See Douglas G. Baird \& Thomas H. Jackson, Fraudulent Conveyance Law and Its Proper Domain, 38 Vand. L. Rev. 829, 832-33 (1985); see also United States v. Gleneagles Inv. Co., 565 F. Supp. 556, 577-79 (M.D. Pa. 1983) (Gleneagles I); United States v. Gleneagles Inv. Co., 571 F. Supp. 935, 951-58 (M.D. Pa. 1983) (Gleneagles II); United States v. Gleneagles Inv. Co., 584 F. Supp. 671, 681-82 (M.D. Pa. 1984) (Gleneagles III), aff'd sub nom. United States v. Tabor Court Realty Corp., 803 F.2d 1288, 1297 (3d Cir. 1986) (invalidating leveraged buyout as fraudulent conveyance under Pennsylvania law); Credit Managers Ass'n v. Fed. Co., 629 F. Supp. 175, 189 (C.D. Cal. 1985) (holding that a leveraged buyout was not a fraudulent conveyance); Anderson Indus., Inc. v. Anderson (In re Anderson Indus.), 55 B.R. 922, 926 (Bankr. W.D. Mich. 1985) (suggesting in dictum that leveraged buyouts could constitute fraudulent conveyances).

${ }^{157}$ Not only is the post-LBO debtor saddled with much more debt than before, but because all (or almost all) of its assets are pledged to secure the LBO financing, few free assets remain available to pay unsecured creditors in case of distress. The subordination of unsecured creditors to secured creditors could occur even in a garden variety financing. In the typical financing however, the borrower firm giving security interests gets to keep the loan proceeds to use in some productive capacity. In the LBO, by contrast, the borrower firm gives up security interests in its assets only to see the loan proceeds funneled out to its equityholders. When the LBO improves the target firm's operating efficiencies, however, the pie is made bigger.

${ }^{158}$ See especially Gleneagles III, 584 F. Supp. at 689-90. 
ments” from fraudulent transfer avoidance actions. ${ }^{159}$ This settlement payments exception was originally meant to address issues peculiar to the clearing and settlement of securities trades made in public securities markets. ${ }^{160}$ Without the exception, a broker executing its client's sale of publicly traded stock in an LBO could potentially have been exposed to fraudulent transfer liability as the "initial transferee" of the fraudulent payment when the firm paid the broker for the stock. ${ }^{161}$

But beginning in 1991, courts expanded that safe harbor beyond stockbrokers, applying it to LBO payments to the target shareholders themselves. Those courts viewed the payments to cashed-out stockholders as settlements for stock trades under Section 546(e), even though these transfers from LBO purchasers to target stockholders did not involve the clearance and settlement system that Congress intended to protect. ${ }^{162}$ The decision in Kaiser Steel Corporation v. Pearl Brewing Company purports to discern the plain meaning of "settlement payment" to include essentially any payment to shareholders in consideration for their shares. ${ }^{163}$ (In fact, the statute's definition of settlement payment is circular and self-referential, not plain.) Subsequent decisions expanded the definition of "settlement payment" further to include payments to shareholders in LBOs of privately held firms. ${ }^{164}$ In the jurisdictions in

${ }^{159} 11$ U.S.C. § 546(e) (2006). It insulates other types of payments and applies to other forms of avoidance as well, but not to transfers made with actual fraudulent intent. Id.

${ }^{160}$ Bankruptcy of Commodity and Securities Brokers: Hearings Before the Subcomm. on Monopolies \& Commercial Law of the H. Comm. on the Judiciary, 97th Cong. 165 (1981) (testimony of Edmund R. Schroeder, Attorney, Barrett Smith Schapiro Simon \& Armstrong) ("If a firm or a clearing organization had to return margin payments received from a debtor when he had already transmitted those funds to others in the clearing chain, its finances could be seriously undermined to the point where it also might be driven into bankruptcy .... [W] hen these moneys flow through the clearing chain, they are disbursed in many different directions, and there is really no way of tracing where they have gone. Any other firm in the chain would stand to have its own capital exposed if there were an attempt to recover these moneys.").

161 11 U.S.C. § 550(a)(1) (2006).

${ }^{162}$ Lowenschuss v. Resorts Int'l (In re Resorts Int'l), 181 F.3d 505, 516 (3d Cir. 1999); Kaiser Steel Corp. v. Pearl Brewing Co. (In re Kaiser Steel Corp.), 952 F.2d 1230, 1240 (10th Cir. 1991). But see Munford v. Valuation Research Corp. (In re Munford, Inc.), 98 F.3d 604, 610 (11th Cir. 1996) (refusing to apply § 546(e) to LBO payments to public company shareholders); Wieboldt Stores ex rel. Raleigh v. Schottenstein, 131 B.R. 655, 665 (N.D. Ill. 1991).

${ }^{163}$ Kaiser Steel Corp., 952 F.2d at 1239-40.

${ }^{164}$ QSI Holdings v. Alford (In re QSI Holdings), 571 F.3d 545, 550 (6th Cir. 2009); Contemporary Indus. Corp. v. Frost, 564 F.3d 981, 989 (8th Cir. 2009); Brandt v. B.A. Capital Co. LP (In re Plassein Int'l Corp.), 388 B.R. 46, 49 (D. Del. 2008). 
which these views prevail, shareholders' LBO priority jump over the firm's unsecured creditors has been preserved.

The jump here did not result from congressional lobbying, but from aggressive, creative litigation that bent existing statutory language to a novel and unanticipated use. Given the current divergent views of courts across the federal circuits, we can expect continuing investments in litigation to extend, preserve, or oppose this LBO priority jump. Priority was shifted in a major way and now, realistically, only Congress could adjust it back.

\section{Section 510(b) and Fair Funds Securities Fraud Distributions}

Before 2002, civil penalties assessed by the Securities and Exchange Commission for securities law violations were deposited with the U.S. Treasury. Then, with the 2002 enactment of the Sarbanes-Oxley Act's "Fair Funds Provision," 165 Congress gave the SEC discretion to distribute these funds to the victims of the related securities law violations. If the penalized issuer is in bankruptcy, however, distribution of value to equityholders in satisfaction of securities fraud claims directly contradicts Section 510(b) of the Bankruptcy Code, which subordinates equityholders' securities laws fraud claims to all other creditors' claims. ${ }^{166}$

The rationale for Section 510(b) is that the risks of illegal issuance of equity securities should be borne by equityholders, and not by creditors. ${ }^{167}$ To place securities fraud claims on a par with general creditor claims would be inconsistent with the absolute priority rule, since it would force creditors to bear equity risk, even though creditors do not enjoy the unlimited returns that equityholders would in the case of the

\footnotetext{
${ }^{165}$ Sarbanes-Oxley Act of 2002, Pub. L. No. 107-204, § 308(a), 116 Stat. 745, 784-85 (codified at 15 U.S.C. § 7246(a) (2006)).

${ }^{166}$ Section 510(b) subordinates claims related to the purchase or sale of the debtor's securities to all claims that are senior or equal to the claims or interests represented by those securities. If the security is common stock, the claim enjoys the same priority as common stock.

${ }^{167}$ H.R. Rep. No. 95-595, at 195 (1977), reprinted in 1978 U.S.C.C.A.N. 5963, 6156 ("Placing rescinding share holders on a parity with general creditors shifts the risk of an illegal stock offering to general creditors. The general creditors have not had the potential benefit of the proceeds of the enterprise deriving from ownership of the securities and it is inequitable to permit [share holders] that have had this potential benefit to shift the loss to general creditors.”).
} 
firm's success. The rationale is contestable and perhaps incorrect, ${ }^{168}$ but the priority structure embedded in Section 510(b) is clear.

Because financial distress often follows financial fraud, it is unsurprising that major financial scandals of the past decade involved securities fraud allegations and settlements with the SEC that led to Fair Funds distributions. These settlements also triggered bankruptcy priority concerns. In the bankruptcies of WorldCom, Inc. and Adelphia Communications Corp., the debtors settled securities fraud allegations by paying, respectively, $\$ 2.25$ billion and $\$ 715$ million in penalties to the SEC. ${ }^{169}$ The courts approving those settlements assumed that the government would distribute the funds to shareholders. ${ }^{170}$ Creditors objected to the settlements in both cases, arguing that any distribution to equityholders would violate Section 510(b) of the Bankruptcy Code. ${ }^{171}$ But the courts in both cases-though recognizing the tension between the Fair Funds provisions and Section 510(b) - held the latter provision to be inapplicable, since any anticipated distributions to equityholders would not be bankruptcy plan distributions, but distributions of funds owned by the government. ${ }^{172}$

In terms of our rent-seeking framework, the Fair Funds priority jump is not a legislative lobbying story, but more a story involving appeal to agency discretion - here, the SEC. The Fair Funds provision was not the product of an organized attempt to obtain a legislative jump in bankruptcy priority (although some proponents may have recognized the potential conflict with Section 510(b)). Instead, it was part of SarbanesOxley's attempt to improve investor confidence by simply providing the

\footnotetext{
${ }^{168}$ Kenneth B. Davis, Jr., The Status of Defrauded Securityholders in Corporate Bankruptcy, 1983 Duke L.J. 1, 3.

${ }^{169}$ Press Release, Sec. Exch. Comm'n, The Honorable Jed Rakoff Approves Settlement of SEC's Claim for a Civil Penalty Against Worldcom (July 7, 2003), available at http://www.sec.gov/news/press/2003-81.htm [hereinafter SEC WorldCom Press Release]; Press Release, Sec. Exch. Comm'n, SEC and U.S. Attorney Settle Massive Financial Fraud Case Against Adelphia and Rigas Family for $\$ 715$ Million (April 25, 2005), available at http://www.sec.gov/news/press/2005-63.htm [hereinafter SEC Adelphia Press Release].

${ }^{170}$ See SEC WorldCom Press Release, supra note 169 ("Under the terms of the settlement, the funds paid and the common stock transferred by WorldCom to satisfy the Commission's judgment will be distributed to victims of the company's fraud, pursuant to Section 308 (Fair Funds For Investors) of the Sarbanes-Oxley Act of 2002.”); SEC Adelphia Press Release, supra note 169 ("Upon the forfeiture of these assets, Adelphia . . . will pay $\$ 715$ million into a victim fund to be established in the District Court ....”).

${ }^{171}$ Official Comm. of Unsecured Creditors of WorldCom, Inc. v. SEC, 467 F.3d 73, 75 (2d Cir. 2006); In re Adelphia Commc’ns Corp., 327 B.R. 143, 147 (Bankr. S.D.N.Y. 2005).

${ }^{172}$ WorldCom, 467 F.3d at 85; Adelphia, 327 B.R. at 169.
} 
possibility for some recovery to defrauded investors outside the realm of private securities fraud litigation. The funds are not generated for the purpose of providing compensation, and they are not peculiar to bankruptcy; instead, they result from penalties and disgorgements assessed by the SEC to deter fraud. Moreover, as Judge Rakoff noted in SEC $v$. WorldCom, the SEC may not set the penalty against a debtor in bankruptcy with the primary goal of compensating investors. ${ }^{173}$ Any distribution to defrauded equityholders is within the SEC's discretion. It is not a bankruptcy distribution, insofar as payments do not come directly from the estate as part of the reorganization process. Instead, it is ultimately to the SEC that investors must turn for any recovery and for what de facto is a priority jump.

\section{B. Historical Priority Jumps}

Priority jumping was part of reorganization practice even before there was a formal bankruptcy statute. This Section describes important priority jumps in equity receiverships and Chapter $\mathrm{X}$ of the Bankruptcy Act, the two reorganization regimes that preceded current Chapter 11.

\section{Marshaling}

Where a creditor holds liens on multiple items of collateral, the equitable doctrine of marshaling requires that the creditor look first to property on which it holds an exclusive lien before looking to collateral encumbered by junior interests. ${ }^{174}$ In effect, marshaling prevents a senior lienor from wiping out the interests of junior lienors when the senior lienor has the option of turning to other collateral to satisfy its claim. The applicability of the marshaling doctrine in bankruptcy is contested, creating opportunities for both priority jumping and defense against it.

Marshaling in bankruptcy arguably effects a priority jump. Junior lienors' interests would otherwise be eliminated if the trustee were allowed to apply shared collateral to a senior creditor's claim. Instead, marshaling assures some recovery to junior lienors from their junior collateral position, depleting assets otherwise available to unsecured credi-

\footnotetext{
173 SEC v. WorldCom, Inc., 273 F. Supp. 2d 431, 434 (S.D.N.Y. 2003).

174 The three prerequisites to marshaling are: (1) contesting parties must be lien creditors of the same debtor; (2) there must be two funds belonging to the debtor; and (3) one creditor alone must have the right to resort to both funds. See Irving D. Labovitz, Marshaling Under the UCC: The State of the Doctrine, 99 Banking L.J. 440, 442 (1982).
} 
tors, whose pro rata share of the estate would increase if junior liens were eliminated.

This priority jump has engendered both defensive efforts and attempts to extend marshaling to other areas. Marshaling is subject to several common law restrictions. ${ }^{175}$ For example, it is generally unavailable when it would disadvantage another lienor. ${ }^{176}$ Unsecured creditors have argued that marshaling in bankruptcy violates that restriction: ${ }^{177}$ Because Bankruptcy Code Section 544(a) endows the trustee with the rights of a lien creditor, marshaling against the bankruptcy estate constitutes marshaling against lienors. ${ }^{178}$ The Ninth Circuit has adopted this view. ${ }^{179}$

Unsecured creditors have also attempted to extend marshaling in bankruptcy beyond its original context, arguing that equity principles allow unsecured creditors to marshal against a debtor's guarantors. ${ }^{180}$ Courts including the Eighth Circuit have accepted this argument, effectively permitting unsecured creditors-acting through the bankruptcy trustee- to force secured creditors to proceed against property owned by a debtor's guarantors before seeking recovery from the estate. Although neither of these deviations from traditional marshaling doctrine is without controversy ${ }^{181}$ their success suggests that priority in the marshaling context is unsettled and likely to continue drawing resources to the fray.

\footnotetext{
${ }^{175}$ For examples, see Lynn M. LoPucki \& Elizabeth Warren, Secured Credit: A Systems Approach 561-68 (7th ed. 2012). Prejudice to unsecured creditors, however, is generally not considered in the marshaling context. In re Robert E. Derecktor of R.I., Inc., 150 B.R. 296, 299-300 (Bankr. D.R.I. 1993) ("While it is clear that marshaling . . will deplete the fund otherwise available to unsecured creditors, we do not find such a result to constitute legal prejudice, in the marshaling context." (emphasis omitted)).

${ }^{176}$ Meyer v. United States, 375 U.S. 233, 237 (1963) (noting that state courts decline to marshal assets "where the rights of third parties ... would be prejudiced"). But see LoPucki \& Warren, supra note 175, at 565 (observing that courts are split on applicability of marshaling in situations where first lienor may seek payment from either of two funds, each encumbered by subordinate liens).

${ }^{177}$ See, e.g., Owens-Corning Fiberglas Corp. v. Ctr. Wholesale (In re Ctr. Wholesale), 759 F.2d 1440, 1447 (9th Cir. 1985).

${ }^{178}$ Id.

${ }^{179} \mathrm{Id}$.

${ }^{180}$ Berman v. Green (In re Jack Green's Fashions for Men-Big and Tall), 597 F.2d 130, 133 (8th Cir. 1979); In re Multiple Servs. Indus., 18 B.R. 635, 637 (Bankr. E.D. Wis. 1982).

${ }^{181}$ See, e.g., Peoples Bank v. Computer Room, Inc. (In re The Computer Room, Inc.), 24 B.R. 732, 737 (Bankr. N.D. Ala. 1982); Whirlpool Corp. v. Plad, Inc. (In re Plad, Inc.), 24 B.R. 676, 680 (Bankr. M.D. Tenn. 1982); Stuhley v. U.S. Small Bus. Admin. (In re United Med. Research), 12 B.R. 941, 944 (Bankr. C.D. Cal. 1981); Labovitz, supra note 174, at 445-46; Moses Lachman, Note, Marshaling Assets in Bankruptcy: Recent Innovations in the Doctrine, 6 Cardozo L. Rev. 671, 689 (1985).
} 


\section{The Equity Receivership}

The end of the nineteenth century saw a spate of large railroad failures. There was no bankruptcy statute to facilitate reorganization, so federal courts grafted the equity receivership onto the litigation to create a precursor to modern Chapter $11 .^{182}$

In the railroad receivership, the receiver could issue receiver's certificates, which functioned like modern DIP loans. More importantly, the receiver could sell the railroad. The purchaser was often a group of the railroad's preexisting creditors, who bid in their debt to pay for the purchase. Creditors excluded from the bidding group were frozen out, enabling the bidding group to jump priority by cutting other creditors out of any future stake in the reorganized railroad. The early reorganization cases focused on the methods of putting priority back in order.

\section{Chapter X Valuation}

In 1938, Congress comprehensively updated bankruptcy law. ${ }^{183}$ Chapter $\mathrm{X}$ of the update was designed primarily by the Securities and Exchange Commission for the reorganization of public companies. ${ }^{184}$ The statute had a New Deal feel to it, with judicial administration of the enterprise central to the proceeding. Pre-bankruptcy management was ousted in favor of a court-appointed trustee, distribution was supposed to follow strict absolute priority, and judicial valuation of the enterprise determined how far down the capital structure value could be distributed. The highest-ranking creditors were paid in full. At the claimant class where value was insufficient for full payment, creditors received pro rata payment. Lower-ranking creditors and stockholders were wiped out. ${ }^{185}$

Though strict absolute priority was enacted in principle, judicial valuation in practice quickly altered the terrain. Courts sought to quell dissent and litigation. Overvaluation accomplished this by squeezing lower-

\footnotetext{
${ }^{182}$ Stephen J. Lubben, Railroad Receiverships and Modern Bankruptcy Theory, 89 Cornell L. Rev. 1420, 1421-22 (2004).

${ }^{183}$ Act of June 22, 1938, ch. 575, 52 Stat. 840, repealed by Bankruptcy Reform Act of 1978, Pub. L. No. 95-598, 92 Stat. 2549.

${ }^{184}$ Eugene V. Rostow \& Lloyd N. Cutler, Competing Systems of Corporate Reorganization: Chapters X and XI of the Bankruptcy Act, 48 Yale L.J. 1334, 1335 (1939).

${ }^{185}$ The valuation was "employed to foreclose the interests of junior classes of creditors and stockholders, and no securities [would] be given any class unless all prior classes [were] 'fully compensated.'” Id. at 1346. For a general discussion of Chapter X's operation, see David A. Skeel, Jr., An Evolutionary Theory of Corporate Law and Corporate Bankruptcy, 51 Vand. L. Rev. 1325, 1370 (1998).
} 
ranking creditors, and sometimes stockholders, into the distribution. Judges seemingly felt that a "full" - that is, high-valuation of the enterprise was in order. ${ }^{186}$ Market values were distrusted. After all, when the firm recovered, it would be worth more, in ways that current valuation did not capture. ${ }^{187}$ By allowing junior claimants to share in the bankruptcy distribution, judicial overvaluation enabled those juniors to jump the priority of higher-ranking creditors.

\footnotetext{
${ }^{186}$ In re Atlas Pipeline Corp., 39 F. Supp. 846, 848 (W.D. La. 1941); Note, Giving Substance to the Bonus Rule in Corporate Reorganizations: The Investment Value Doctrine Analogy, 84 Yale. L.J. 932, 933-39 (1975).

${ }^{187}$ Moreover, overvaluation was structurally more likely since undervaluation would elicit bids that would drive the valuation toward the proper value. Overvaluation, by contrast, lacked this self-corrective mechanism. See Walter J. Blum, Full Priority and Full Compensation in Corporate Reorganizations: A Reappraisal, 25 U. Chi. L. Rev. 417, 419 (1958); Walter J. Blum \& Stanley A. Kaplan, The Absolute Priority Doctrine in Corporate Reorganizations, 41 U. Chi. L. Rev. 651, 655-61 (1974); Walter J. Blum, The Law and Language of Corporate Reorganization, 17 U. Chi. L. Rev. 565, 566 (1950); Note, supra note 186, at 933.
} 